\title{
SOLAR INFORMATION PROCESS MODEL
}

DO NOT MICROFILM

THIS PAGE 


\section{DISCLAIMER}

This report was prepared as an account of work sponsored by an agency of the United States Government. Neither the United States Government nor any agency Thereof, nor any of their employees, makes any warranty, express or implied, or assumes any legal liability or responsibility for the accuracy, completeness, or usefulness of any information, apparatus, product, or process disclosed, or represents that its use would not infringe privately owned rights. Reference herein to any specific commercial product, process, or service by trade name, trademark, manufacturer, or otherwise does not necessarily constitute or imply its endorsement, recommendation, or favoring by the United States Government or any agency thereof. The views and opinions of authors expressed herein do not necessarily state or reflect those of the United States Government or any agency thereof. 


\section{DISCLAIMER}

Portions of this document may be illegible in electronic image products. Images are produced from the best available original document. 


\title{
Solar Information Process Model
}

\author{
R. Hewett \\ P. Spewak
}

MTR- -7969

DE83 016955

\section{December 1978}

ACOI-78C535144

\section{DISCLAIMER}

This report was prepared as an account of work sponsored by an agency of the United States Government. Neither the United States Government nor any agency thereof, nor any of their employees, makes any warranty, express or implied, or assumes any legal liability or responsibility for the accuracy, completeness, or usefulncss of any information, apparatus, producl, or process disclosed, or represents that its use would nnt infringe privately owned rights. Reference herein to any specific commercial product, process, or service by trade name, trademark, manufacturer, or otherwise does not necessarily constitute or imply its endorsement, recommendation, or favoring by the United States Government or any agency thereof. The views and opinions of authors expressed herein do not necessarily state or reflect those of the United States Government or any agency thereof.

The MITRE Corporation

Metrek Division

Contract No.: EG-77-C-01-4041

Project No.: 16180

Dept.: W-52
1820 Dolley Madison Boulevard

McLean, Virginia 22102

MITRE Technical Report MTR-7969 


\section{THIS PAGE \\ WAS INTENTIONALLY \\ LEFT BLANK}




\begin{abstract}
The MITRE Solar Information Process Model (SIP) is a computerized model that simulates information processes in solar markets. As such, it represents a useful tool in the formulation of solar information outreach programs. For each market investigated, SIP model outputs include prioritized listings of the information needs of key decision makers and other strategically important market participants, and related information flow paths. This report provides macro-descriptions of the model and its logic together with a detailed illustrative example of its application. It also presents the findings and conclusions resulting from utilization of the model in the analysis of information processes in eight solar markets within the residential, commercial and agricultural sectors.
\end{abstract}




\section{ACKNOWLEDGEMENTS}

The authors wish to thank Marie Coluzzi for the support she provided not only in model programming but also in converting input data generated by the authors into machine sensible form, entering the data and executing model runs. 
FOREWORD

This document is one of a series of interrelated technical reports resulting from the "Analytic Tools and Strategies for Solar Energy Technology Transfer" study performed by The MITRE Corporation, Metrek Division, for the U.S. Department of Energy. Other reports in the series are:

- Solar Information Outreach Strategies and Action Plans (MTR-7971)

- Solar Energy Technology Transfer Source Book (MTR-7674)

- Volume I: Buildings

- Volume II: Agriculture

- Solar Information Outreach Monitoring and Action Plan Assessment System (MTR-7972).

Technical Report MTR-7971, catalogs recommended information outreach action plans and strategies aimed at addressing important solar-related concerns, problems and needs of important participants in the solar markets relating to water and space heating in buildings and agricultural process heat applications. The MITRE Solar Information Process Model--the subject of this document--is one of the resources used in formulating the strategies and action plans documented in MTR-7971.

The Source Book (MTR-7674) is a convenient source of related reference data and serves as an aid in the planning and management of market-specific solar information outreach initiatives. In addition, it provides names and addresses of many of the entities (e.g., manufacturers, architects, financlers, etc.) that have strategic roles in solar market development.

Technical Report MTR-7972, provides the design concept and functional specifications for a DOE Solar Information Outreach Monitoring and Action Plan Assessment System. The objective of this system is to assist DOE to keep abreast of solar market development and needs and to assess the effectiveness of its solar information outreach initiatives. 


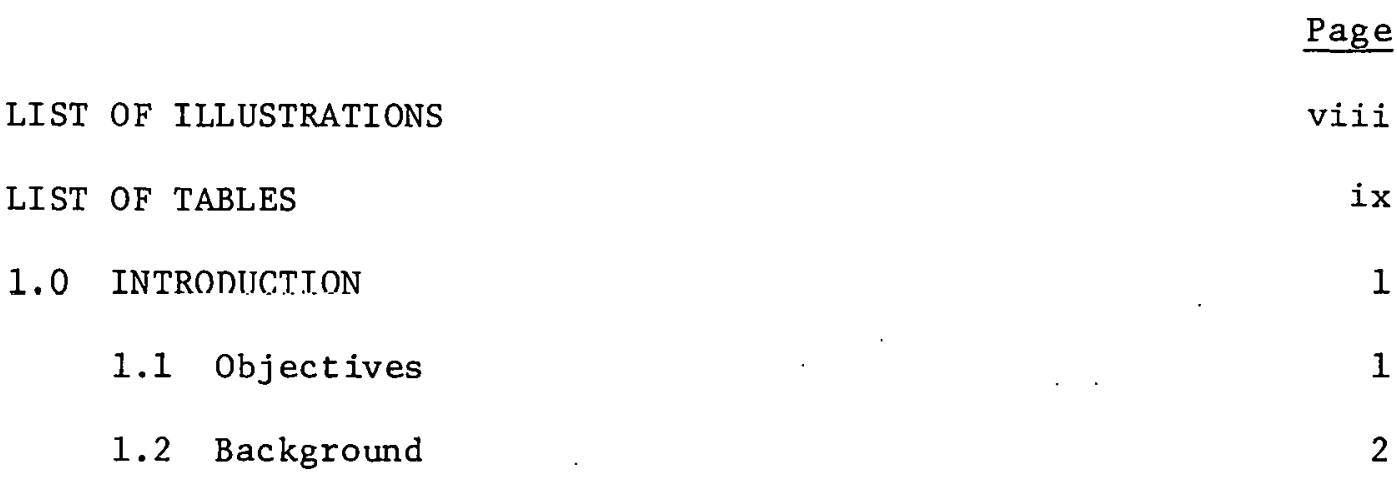

2.0 SOLAR INFORMATION PROCESS MODEL: LOGIC AND PROCESSING 5

2.1 Model Logic: Macro Description 5

2.2 Mode1 Inputs, Processing and Outputs 8

2.2.1 Model Inputs . 8

2.2.2 Model Processing 8

2.2.3 Model Outputs 13

3.0 APPLICATION OF THE MODEL USING A HYPOTHETICAL EXAMPLE 17

$\begin{array}{lll}3.1 & \text { Example Inputs } & 17\end{array}$

$\begin{array}{ll}3.2 & \text { Processing of the Example } \\ \end{array}$

3.2.1 Computation of Primary Benefits 27

3.2.2 Development of Information Chains 30

3.2.3 Computation of Secondary Benefits . 32

3.2.4 Computation of Total Benefits and Total
Benefit/Cost Ratio

3.3 Results and Conclusions from the Sample Application 37

3.4 Examples of Using MITRE Solar Information Process Model Results to Formulate Information Outreach Initiatives 
4.0 ANALYSIS OF INFORMATION PROCESSES IN SOLAR MARKETS:

RESULTS AND CONCLUSIONS

BIBLIOGRAPHY

DISTRIBUTION LIST

LIST OF ILLUSTRATIONS

Figure Number

$\underline{\text { Page }}$

$2-1$

$2-2$

$2-3$

3-1

Flow Diagram: SIP Program Planning Mode 1

7

MITRE Solar Information Process Model Processing Steps

I1,1ustrative Examples of Alternative Information Flow Paths Over Which Homeowners Satisfy Their Information Needs: One- and Two-Family Homes, Hot Water System Retrofit Market

Examples of Information Chains Developed by the MITRE Solar Information Proceoo Mode1

\section{LIST OF TABLES}

Table Number

Page

II-1

MITRE Solar Information Process Model

Input Data

9

II-2

MITRE Solar Information Process Model Sample Model Output, New One- and TwoFamily Homes Market (Speculative Construction)

III-1

Relative Importance of the Participants in the Functioning of the Market Under Analysis: Array PRTIMP (Part) 


\section{LIST OF TABLES (Continued)}

Table Number

Page

III -2

Information Needs of Each Participant and the Relative Importance Attached to Those Needs: Input Array INFIMP (PART, INF)

III -3

Information Dissemination Mechanisms and Their Relative Effectiveness: Input Array MCEFF (PART, MEC)

Information Dissemination Mechanisms and Their Relative Comprehension Rates: Input Array COMPR (MEC)

III-5

Cost $(\$, 000)$ to the Government of Using

Each Mechanism to Disseminate Information:

Input Array Cost (INF, MEC)

III-6

Participant-to-Participant Information Transfer Effectiveness: Input Array PTOP (Part 1, Part 2)

III-7

Conversion of the Elements of Each Row of Input Array INFIMP (PART, INF) from the 1-5 Scale to Proportions

Computed Array RELIMP (PART, INF)

Information Dissemination Tasks Ranked According to Primary Benefit/Cost Ratio

Rank-Ordered I isting of the Secondary Benefits Accruing to Participants in the Sample Problem

MITRE Solar Information Process Model Output: Participant/Information Need Tasks Ranked According to Total Benefit/ Cost Ratio

IV-1 Solar Information Proress Functions of Participant Groups Within Building Markets

Solar Information Process Functions of Participant Groups Within the Agricultural Process Heat Markets 
The Most Important Information Needs of Participant Groups, Ranked in Terms of Total Benefits (New One- and TwoFamily Homes Market: Custom Construction)

IV -4

The Most Important Information Needs of Participant Groups, Ranked in Terms of Total Benefits (New One- and TwoFanily llomes Markct: Epcculative Construction)

IV-5

The Most Important Information Needs of Participant Groups, Ranked in Terms of Total Benefits (New Mobile Homes Market)

The Most Important Information Needs of Participant Groups, Ranked in Terms of Total Benefits (One- and Two-Family Homes Retrofit Market, Including Mobile Homes)

The Most Important In Formation Needs of Particlpant Gluups, Ranked in Terms of Toidl Belleflls (New alid Retrofit Commer cial Building Markets)

The Most Important Information Needs of Participant Groups, Ranked in Terms of Total Bonofitc (Agricultura1 Prncess Heat Markers: Rattunal and Tradilioiual Farms) 


\subsection{INTRODUCTION}

\subsection{Objectives}

The Solar Information Process (SIP) model discussed in this report was designed and developed by The MITRE Corporation as part of a study entitled, "Analytic Tools and Strategies for Solar Energy Technology Transfer".* It simulates the net results of information processes in specific solar markets and constitutes a useful analytic tool in the formulation of solar information outreach programs.

Succeding sections describe the model, from the perspective of a DOE solar information outreach program planner, and present findings and conclusions which resulted from applying the model to the analysis of information processes in the following solar markets:

- Water and space heating in residences and commercial buildings

- New one- and two-family homes market (custom construction)

- New one- and two-family homes market (speculative and tract construction)

- New mobile homes market

- One- and two-family homes retrofit market, including mobile homes

- New commercial buildings market

- Commercial buildings retrofit market.

- Agricultural process heat (crop drying and animal shelter heating)

- Rational farms market (i.e., the market in which the farmer characteristically views farming as a business and is usually willing to invest in more efficient capital equipment to control costs)

\footnotetext{
*"Analytic Tools and Strategies for Solar. Energy Technology Transfer," Contract Number EG-77-C-01-4041 between DOE and The MITRE Corporation.
} 
- Traditional farms market (i.e., the market in which the farmer characteristically views farming as a way of 1 ife and prefers to repair existing capital equipment or purchase used rather than new equipment).

More specifically, this report:

- Describes model processing

- Shows, via an example, how the model works and how to interpret model results

- Shows the findings and conclusions resulting from using the midel to analyzc information processes in the ahove-mentioned markets.

A complementary report, MITRE Working Paper $12736^{*}$, provides a technical description of the model and serves as a programmer's guide.

\subsection{Background}

The commercialization of innovative technologies to the point where they achieve significant market penetration is typically a relatively protracted process. During this process, innate conservatism, and initial market uncertainties about the new product, its performance, operating economics, etc., are progressively diluted and eventually overcome. In this context, effective information outreach represents a vital activity in current efforts to accelerate the commercialization of solar energy technologies.

In the development of solar information outreach programs, a wide range of issucs must be addressed. These include:

- For each market, who are the participants, and how do they interact?

\footnotetext{
"M. Coluzzi, K. Rebibo and P. Spewak, "Solar Energy Technology Transfer Mode1--Program Description and Logic" (WP-12736), The MITRE Corporation, 1978.
} 
- Of these participants, who are the principal decision makers? What is their relative impact in decision making processes, and how do they interact?

- What are the major concerns and inhibitions of each of the decision makers with respect to solar systems? What is the relative importance of each such concern?

- What information is needed to ameliorate, and hopefully resolve, such concerns?

- What are the most effective means of getting the most important information to the most important participants/decision makers, taking into account:

- The credence that a particular participant puts in various information sources

- The coverage and impact of alternative disseminating mechanisins

- Cost and time characteristics of alternative information processes?

- Who are the information multipliers in the system? To what extent does providing information to one participant (who may, or may not be a principal decision maker) indirectly satisfy the information needs of other participants?

The SIP model represents a systematic and analytic methodology for integrating data on the above and related issues, to derive outreach activity priorities, and critical information-flow sequences within specific solar markets. 


\subsection{SOLAR INFORMATION PROCESS MODEL: LOGIC AND PROCESSING}

\subsection{Model Logic: Macro Description}

The MITRE/Metrek Solar Information Process model is a quantitative structural model that simulates the net results of information processes in solar markets. That is, the model takes the array of information dissemination tasks--getting each item of information needed by each participant to that participant by the most effective mechanism--and prioritizes them. Prioritization is on the basis of:

- The relative importance of each participant in the functioning of the market under investigation

- The relative importance to each participant of several solarrelated concerns or inhibitions

- The relative importance attached to each item of information needed by each participant with respect to each concern

- Information generation and sequencing; that is, the development of information by combining data and other items of information, and the passing of information between participants. For example, "economic viability" information is developed by combining the following items:

- System procurement and installation cost

- System performance parameters

- Conventional fuel cost

- Maintenance costs

- etc.

Information processes include:

- Production of information from data and other intelligence

- Tailoring of information to the requirements of, and in the language of, each participant who needs it

- Information packaging

- Information dissemination. 
As such, the model is a tool for setting information outreach priorities in the formulation of market-oriented solar information outreach programs.

For each solar market analyzed, the model takes cognizance of:

- Heating, ventilation and air conditioning (HVAC) equipment decisionmaking

- Decision makers and their relative importance in the overall functioning of the market

- Decisionmaking processes

- Market practices

- Interactions between market participants

- Traditional sources of information and other services: who typically gets what from whom

- Information processes

- Information needs of each participant and the relative weight attached to each need

- Information dissemination mechanisms and their attributes, ค. . : :

--Coverage

--Impact

--Cost/Time characteristics

- The construction nf information from data and other intelIigence.

Figure 2-1 depicts the model's logic diagramatically.

The model has utility in the following applications:

- Identification of critical participants by application (i.e., market sector)

- Prioritization of information needs

- By market sector

- By participant

- By region 


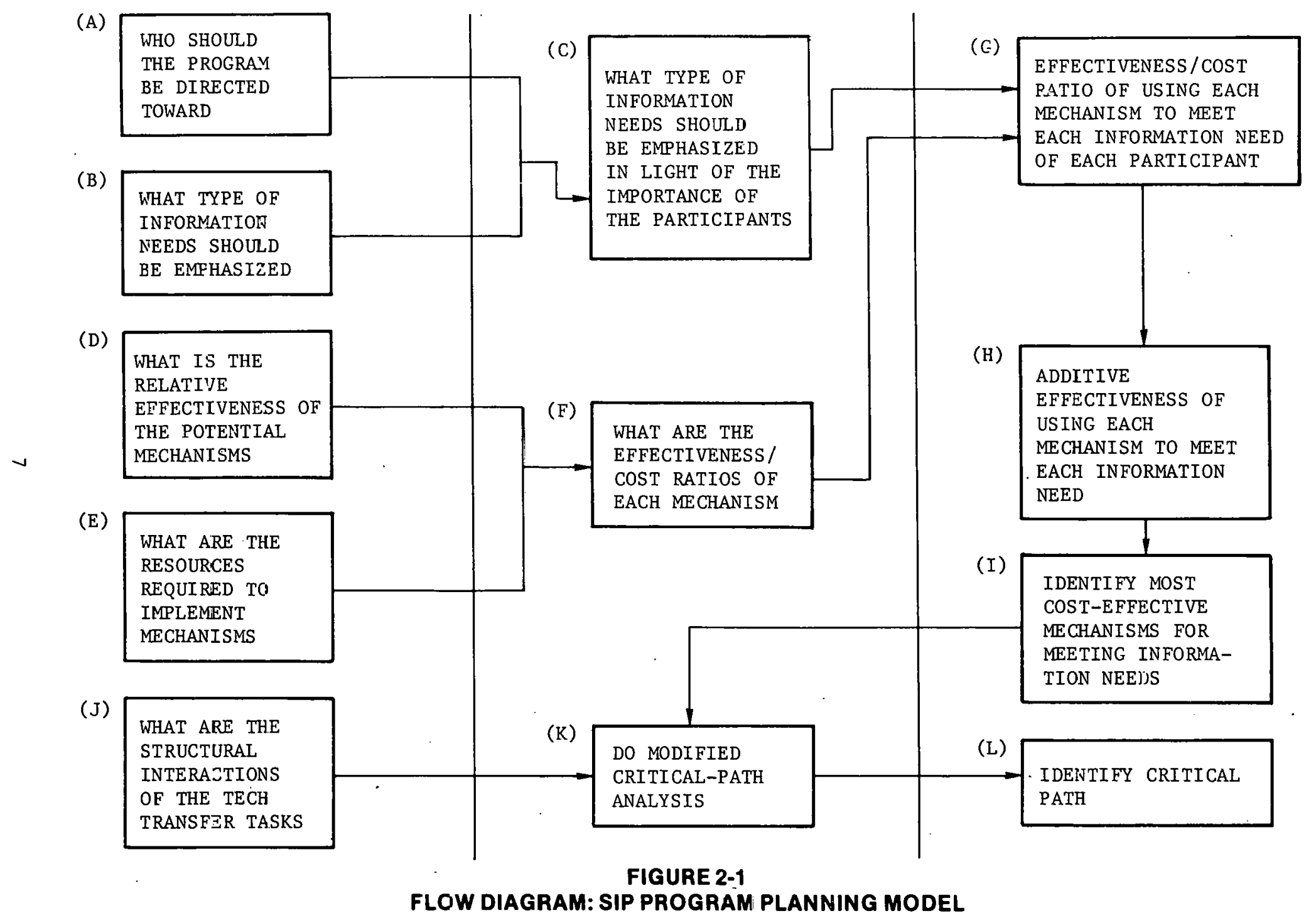


- Prioritization of information dissemination mechanisms by participant group

- Evaluation of interacting group activities

- Prioritization of technology transfer tasks in the light of total impact on a solar market

- Identification of information-flow critical paths (i.e., who needs what information and in what sequence)

- Adjustment of programmatic content and priorities with solar technology transfer evolution (i.e., feedback from program tracking).

\subsection{Model Inputs, Mrocessing and Uurpurs}

Comprehensive, technical descriptions of model inputs, processing and outputs are provided in MITRE Working Paper 12736.*

\section{2 .1 Model Inputs}

Mode1 inputs consist of quantitative measures of:

- Participants and their relative importance

- Information processes

- Information production

- Information transfer between participants

- Information dissemination mechanisms (e.g., relative coverage, impact, cost, etc.)

Descriptions and examples of the most important model inputs are provided in Table II-1. Additional examples are provided in Section 3.0.

\subsubsection{Mode1 Processing}

Higure $2-2$ summarizes the major steps involved in model proces sing. Essentially, the model determines overall information outreach

\footnotetext{
*op. cit.
} 
TABLE II-1

MITRE SOLAR INFORMATION PROCESS MODEL INPUT DATA

\begin{tabular}{|c|c|c|}
\hline & Input Arrays & Array Definitions \\
\hline (1) & PRTIMP (PART) & $\begin{array}{l}\text { - Relative importance of the partici- } \\
\text { pants within the functioning of the } \\
\text { market under analysis (Scale: } 0-1 \text { ) }\end{array}$ \\
\hline (2) & COMPRE (MEC) & $\begin{array}{l}\text { - Comprehension rate of each mechanism } \\
\text { (Scale: } 0-1)\end{array}$ \\
\hline (3) & INFIMP (PART, INF) & $\begin{array}{l}\text { - Relative importance of each item of } \\
\text { information to each market partici- } \\
\text { pant (Scale: 1-5) }\end{array}$ \\
\hline (4) & MECEFF (PART, MEC) & $\begin{array}{l}\text { - Relative effectiveness of each } \\
\text { information dissemination mechanism } \\
\text { for each participant (Scale: } 0-1 \text { ) }\end{array}$ \\
\hline (5) & $\operatorname{COST}$ (INF, MEC) & $\begin{array}{l}\text { - Cost of each information mechanism } \\
\text { for each information need (thousands } \\
\text { of dollars) }\end{array}$ \\
\hline (6) & $\begin{array}{l}\text { PRDCSR (PART1, INF, } \\
\text { PART2) }\end{array}$ & $\begin{array}{l}\text { - Participants who can meet the infor- } \\
\text { mation needs of other participants } \\
(0=\text { No, } 1=\text { Yes })\end{array}$ \\
\hline (7) & $\begin{array}{l}\text { PTOP (PART1, PART2 } \\
\text { NPRT) }\end{array}$ & $\begin{array}{l}\text { - Participant-to-participant effective- } \\
\text { ness of information transfer } \\
\text { (Scale: } 0-1)\end{array}$ \\
\hline (8) & INFINF (INF 1, INF2) & $\begin{array}{l}\text { - Information needs that are required } \\
\text { to compute other information needs } \\
(0=\text { No, } 1=\text { Yes })\end{array}$ \\
\hline
\end{tabular}

PART $=$ Participant

$\mathrm{MEC}=$ Information Dissemination Mechanism

INF = Information Need 


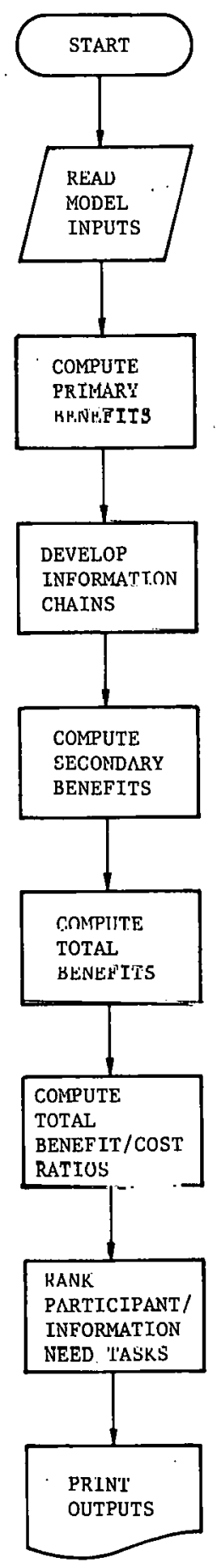

FIGURE 2-2

MITRE SOLAR INFORMATION PROCESS MODEL PROCESSING STEPS 
priorities within each market sector, according to a specified criterion.

Ideally, one would prefer to determine information dissemination priorities on the basis of a (validated) relationship which expresses solar market penetration as a function of the quantity of information disseminated to the most important market participants by content (subject matter), quantity and dissemination mode. This would provide a rational, analytic basis for allocating available resources. However, at the present time, the knowledge to construct such a function is not available. Furthermore, the dissemination of information to strategic and important market participants does not alter other parametric variables that critically influence market acceptance. For example, the dissemination of solar-related information to developers, homeowners, financiers, utilities, etcc. does not:

- Make solar systems less expensive

- Alter their economic viability

- Change the payback period

- Alter the cost of conventional fuels

- Make solar systems perform better or give them greater reliability.

Hence, it was necessary to develop another criterion for determining information outreach priorities. The criterion ultimately adopted was information benefit, defined as the relative impact on the market under investigation of meeting a specific information need of a specific participant. This criterion is predicated upon the following as sumption: 
- If all items of information needed by all market participants were met, and if information transfer processes were 100 percent effective, then there would be 100 percent impact.

The 100 percent impact represents potential impact. Actual

impact is vastly smaller than 100 percent because of inefficiencies in the information processes. Among these are:

- Incomplete coverage: information dissemination mechanisms do not reach 100 percent of the target audience

- Mechanism (e.g., periodicals, workshups, electronie mcdia, erc.) inefliciencies: no mcchaniem transmits informaliun with complete effectiveness to all members of the audience it cuvers

- Participant-to-participant transfer inefficiencies: the processes whereby one participant category personally conveys information to another participant are less than perfect.

Model processing involves allocating the actual impact among the set of participant/information need combinations. For example, if there are 20 participants and if each has 10 information needs, there are 200 participant/ information need combinations. The model allocates the available actual percentage of impact among the 200 participant/information need combinations. Three types of information benefits are calculated:

- Primary benefits: benefits that result when a participant group which receives information (regardless of source) uses that information to satisfy its own needs

- Secondary benefits: benefits which accrue to a participant gruup when it passco information which it receives to others. For example, if a solar equipment dealer receives "economic viability" information from a manufacturer, repackages it and then disseminates it to a potential solar system buycr, that dealer accrues secondary benefits

- Total benefits: the sum of primary and secondary benefits. Total benefits and the total benefit/cost ratio are used to establish information outreach priorities. 


\subsubsection{Model Outputs}

The principal model outputs are:

- Totality of all participant/information need combinations ranked in terms of:

- Total benefits

- Total benefit/cost ratio.

- Information flow paths: the alternative paths over which information flows to participant groups that need it. Figure 2-3 provides illustrative examples of alternative information flow paths.

- Specific information needs of each participant group:

- Benefits (i.e., primary, secondary, and total benefits) which accrue by meeting these needs

- The best three mechanisms for disseminating each item of needed information

- The benefit/cost ratio of the best information dissemination mechanism for meeting each need.

Table II-2 shows examples of participant/information need combinations ranked according to total benefits, specifically for the new one and two family homes speculative construction market. 


$\begin{gathered}\text { Paths Over Which Homeowners Can Obtain } \\ \text { Information about Tax Incentive Programs }\end{gathered}$
$(1) \rightarrow$ Federal System Integration Agencies $\rightarrow$ Homeowners
$(2) \rightarrow$ Federal System Integration Agencies $\rightarrow$ Solar Equipment
Manufacturers $\rightarrow$ Homeowners
$(3) \rightarrow$ Federal System Integration Agencies $\rightarrow$ Solar Equipment
Manufacturers $\rightarrow$ Mechanical Contractors $\rightarrow$ Homeowners
$(4) \rightarrow$ Federal System Integration Agencies $\rightarrow$ Mechanical
Contractors $\rightarrow$ Homenwers

\begin{tabular}{|c} 
Paths Over Which Homeowners Can Obtain Information \\
Regarding Solar System Performance and Reliability
\end{tabular}

FIGURE 2-3

ILLUSTRATIVE EXAMPLES OF ALTERNATIVE INFORMATION FLOW PATHS OVER WHICH HOMEOWNERS SATISFY THEIR INFORMATION NEEDS: ONE- AND TWO-FAMILY HOMES, HOT WATER SYSTEM RETROFIT MARKET 
TABLE II-2

MITRE SOLAR INFORMATION PROCESS MODEL SAMPLE MODEL OUPUT

NEW ONE- AND TWO-FAMILY HOMES MARKET (SPECULATIVE CONSTRUCTION)

\begin{tabular}{|cl|l|r|}
\hline Task & Participant Group & Information Need Category & $\begin{array}{r}\text { Total } \\
\text { Benefits } \\
\text { Index }\end{array}$ \\
\hline 1 & Equipment Manufacturer & Installation \& Maintenance & 8.685 \\
2 & Equipment Manufacturer & Design/Performance & 7.365 \\
3 & Mechanical Engineer & Design/Performance & 4.186 \\
4 & Mechanical Engineer & Installation \& Maintenance & 3.654 \\
5 & Equipment Manufacturer & List of Installers & 2.550 \\
6 & Equipment Manufacturer & List of Maintainers & 1.878 \\
7 & Mechanical Engineer & Installation \& Maintenance & 1.674 \\
8 & Equipment Manufacturer & Warranties & 1.034 \\
9 & Equipment Manufacturer & List of Designers & 1.002 \\
10 & Mechanical Engineer & Economic Viability & 0.932 \\
\hline
\end{tabular}




\subsection{APPLICATION OF THE MODEL USING A HYPOTHETICAL EXAMPLE}

Section 2.0 provided a macro description of SIP model logic and processing. Section 3.0 shows how the model works by means of a hypothetical example selected to simplify computations and facilitate explanations of processing procedures. The example relates to information processes associated with the one-and-two-family homes retrofit market for solar water heating systems.

\subsection{Example Inputs}

Assume that four participant groups have roles in the decisionmaking and information processes associated with the one- and two-family homes retrofit market for solar water heating systems:

- Home owner

- Solar equipment manufacturer

- Dealer/Installer

- Financier.

Analysis of the decisionmaking processes associated with this market showed that the homeowner is the pre-eminent decision maker with respect to equipment selection. * However, decisionmaking by the homeowner is influenced by the actions of manufacturers and dealers; specifically:

- The manner in which they market their products

- Their ability to provide, persuasively, the information needed by homeowners to make decisions

\footnotetext{
${ }^{\star} R$. Hewett, et al., Solar Energy Technology Transfer Source Book, Volume I: Buildings (MTR-7674), The MITRE Corporation, 1978. .
} 
- Their ability to support their products (i.e. provide quality installation and maintenance services and replacement parts).

Unless the homeowner has self-financing capability, a decision on his part to opt for solar also requires the concurrence of the financier. Hence, although the homeowner is the pre-eminent decision maker, others have important roles in the process. Table. III-1 shows the assumptions used in the example regarding the relative influence of each of the four actors in the decisionmaking and information processes associated with the subject market. Table III-1 defines the input array PRTIMP (NPRT).

Table III-2 shows the items of information needed by each of the four participants in the example, and the relative importance attached to each item. For the purposes of this illustrative example, each participant is assumed to have no more than five information needs. These data constitute the inpur array INFIMP (NFRT, NINF) ao dcocribed in Subsection 2.2.1. Table III-2 sliuws Llat manufacturera havo five information needs. However, some of them are not needed by manufacturers for their own consumption. For example, manufacturers require "installation and maintenance" information--not for their own purposes but for dissemination to dealers. Dealers rely upon manufacturers for such information.

In order to satisfy each information need of each participant, an appropriate dissemination mechanism must be chosen. Table III-3 shows the mechanisms assumed to be available to participants and their relative effectiveness: 
TABLE III-1

RELATIVE IMPORTANCE OF THE PARTICIPANTS IN THE

FUNCTIONING OF THE MARKET UNDER ANALYSIS:

ARRAY PRTIMP (PART)

\begin{tabular}{|l|c|c|}
\hline \multicolumn{3}{|c|}{ ARRAY PRT IMP (PART) } \\
\hline Participant & $\begin{array}{c}\text { Participant } \\
\text { Number } \\
\text { (PART) }\end{array}$ & $\begin{array}{c}\text { Relative Importance } \\
\text { PRTIMP (PART) }\end{array}$ \\
\hline Homeowner & 1 & 0.6 \\
Manufacturer & 2 & 0.1 \\
Dealer & 3 & 0.2 \\
Financier & 4 & 0.1 \\
\hline
\end{tabular}


TABLE III-2

INFORMATIJN KEEDS OF EACH PARTICIPANT AND THE RELATIVE INPORTANCE ATTACAED TO THOSE NEEDS: INPLT ARRAY INFIMP (PART, INF)

\begin{tabular}{|c|c|c|c|c|c|c|c|}
\hline \multicolumn{8}{|c|}{ ARRAY INFIMP (PART, INF) } \\
\hline \multirow[b]{2}{*}{ Participants } & \multirow[b]{2}{*}{$\begin{array}{l}\text { Participant } \\
\text { Number } \\
\text { (PART) }\end{array}$} & \multicolumn{6}{|c|}{ Information Needs } \\
\hline & & 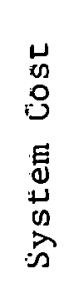 & 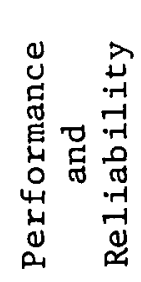 & 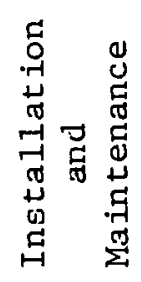 & 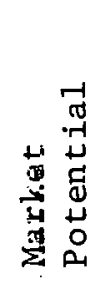 & 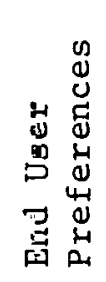 & 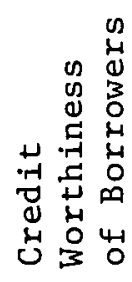 \\
\hline Homeowner & 1 & 5 & 4 & 1 & 1 & 1 & 1 \\
\hline Manufacturer & 2 & 4 & 4 & 4 & 5 & 5 & 1 \\
\hline Dealer & 3 & 3 & 3 & 5 & 4 & 4 & 1 \\
\hline Financier & 4 & 1 & 3 & 1 & 1 & 1 & 5 \\
\hline
\end{tabular}

$\frac{\text { Scale }}{5}$ : Information Needs of Greatest Importance

4 : Information Needs of Great. Importance

3 : Information Needs of Considerable Importance

2 : Informatior Needs of Lesser Importance

1 : Information Needs of No Importance 
TABLE III-3

INFORMATION DISSEMINATION MECHANISMS AND THEIR

RELATIVE EFFECTIVENESS : INPUT ARRAY MCEFF (PART, MEC)

\begin{tabular}{|lc|c|c|c|c|}
\hline \multirow{2}{*}{$\begin{array}{c}\text { Participant } \\
\text { Number } \\
\text { (PART) }\end{array}$} & \multicolumn{4}{|c|}{$\begin{array}{c}\text { Relative Effectiveness of Each } \\
\text { Mechanism MECEFF (PART, MEC) }\end{array}$} \\
\cline { 3 - 6 } & 1 & Television & $\begin{array}{c}\text { Trade } \\
\text { Journals }\end{array}$ & $\begin{array}{c}\text { Inter- } \\
\text { personal }\end{array}$ & NSHCIC* \\
\hline Homeowner & 2 & .3 & .0 & .5 & .2 \\
Manufacturer & 3 & 0 & .8 & .2 & 0 \\
Dealer & 4 & 0 & .4 & .4 & .2 \\
Financier & & 0 & .5 & .5 & 0 \\
\hline
\end{tabular}

*National Solar Heating and Cooling Information Center

Scale: $0-1$ 


\section{- Television}

- Professional and trade journals

- Interpersonal communications (i.e., person-to-person information dissemination)

- National Solar Heating and Cooling Information Center.

The data in Table III-3 define input array MECEFF (PART, MEC). The zero values in any of the cells of array MECEFF (PART, MEC) indicate that mechanism "MEC" is not appropriate for disseminating information to participant "PART." For example, array MECEFF (PART, MEC)--as defined in Table III-3--shows that television is not an appropriate mechanism for conveying information to manufacturers. On the other hand, professional and trade journals are most appropriate for reaching manufacturers.

Mechanism effectiveness is defined to be a function of three measures:

- Coverage: percentage of the target andience reached by Llie mechanism

- Image: credibility of the mechanism as perceived by the target audience

- Efficiency: ease with which information io tranemitted to the target audience, once the audience is reached.

Mechanism effectiveness for each participant category is given by MECEFF $(r \Lambda R T)=$ Coverage $\pi$ Image $x$ Efficiency

For example, the homeowner is widely covered by television (assume 80 percent coverage). However, a typical homeowner might believe only 60 percent of the things he hears or sees on television--a less than 
perfect image. Then too, the homeowner may not absorb all the information presented--assume 63 percent. Hence, for homeowners, the mechanism effectiveness of television is $80 \% \times 60 \% \times 63 \%$ or 30 percent.

In reality, of course, mechanism effectiveness is a much more complex phenumenon than the multiplication function given above.

In addition to differences in the effectiveness of different information dissemination mechanisms, the model takes cognizance of differences in relative comprehension rates. Table III-4 shows the comprehension rates assumed for each of the four mechanisms.

Table III-5 shows the costs to the Federal Government, in thousands of dollars, of using alternative mechanisms to satisfy the various information needs of participants. These values constitute input array $\cos T$ (INF, MEC). Array $\cos T$ (INF, MEC) does not take cognizance of differences in participants. That is, it gives the cost of using specific mechanisms to meet specific information needs without taking into account the specific participant which has that need.

Tablc III. 6 shuws the effectiveness of participant-to-participant information transfers. These values define input array PTOP (PART 1, PART 2). Table III-6, for example, shows that dealers are more effeclive in conveying solar-related information to homeowners than manufacturers. 
TABLE III-4

INFORMATION DISSEMINATION MECHANISMS AND THEIR RELATIVE

COMPREHENSION RATES: INPUT ARRAY COMPRE (MEC)

\begin{tabular}{|c|c|c|}
\hline \multicolumn{3}{|c|}{ ARRAY COMPRE (MEC) } \\
\hline Mechanism & $\begin{array}{c}\text { Mechanism } \\
\text { Number }\end{array}$ & $\begin{array}{l}\text { Relative } \\
\text { Compreliension } \\
\text { Rate } \\
\text { (CUUVPRE (MES)) }\end{array}$ \\
\hline 'l'elevision & 1 & .8 \\
\hline $\begin{array}{l}\text { Professional and } \\
\text { Trade Journals }\end{array}$ & 2 & .6 \\
\hline Intcrpersonal & 3 & .8 \\
\hline NSHCIC * & 4 & .6 \\
\hline
\end{tabular}

*National Solar Heating and Conling Information Center Scale: $0-1$ 
TABLE III-5

COST $(\$, 000)$ TO THE GOVERNMENT OF USING EACH MECHANISM

TO DISSEMINATE INFORMATION: INPUT ARRAY COST (INF, MEC)

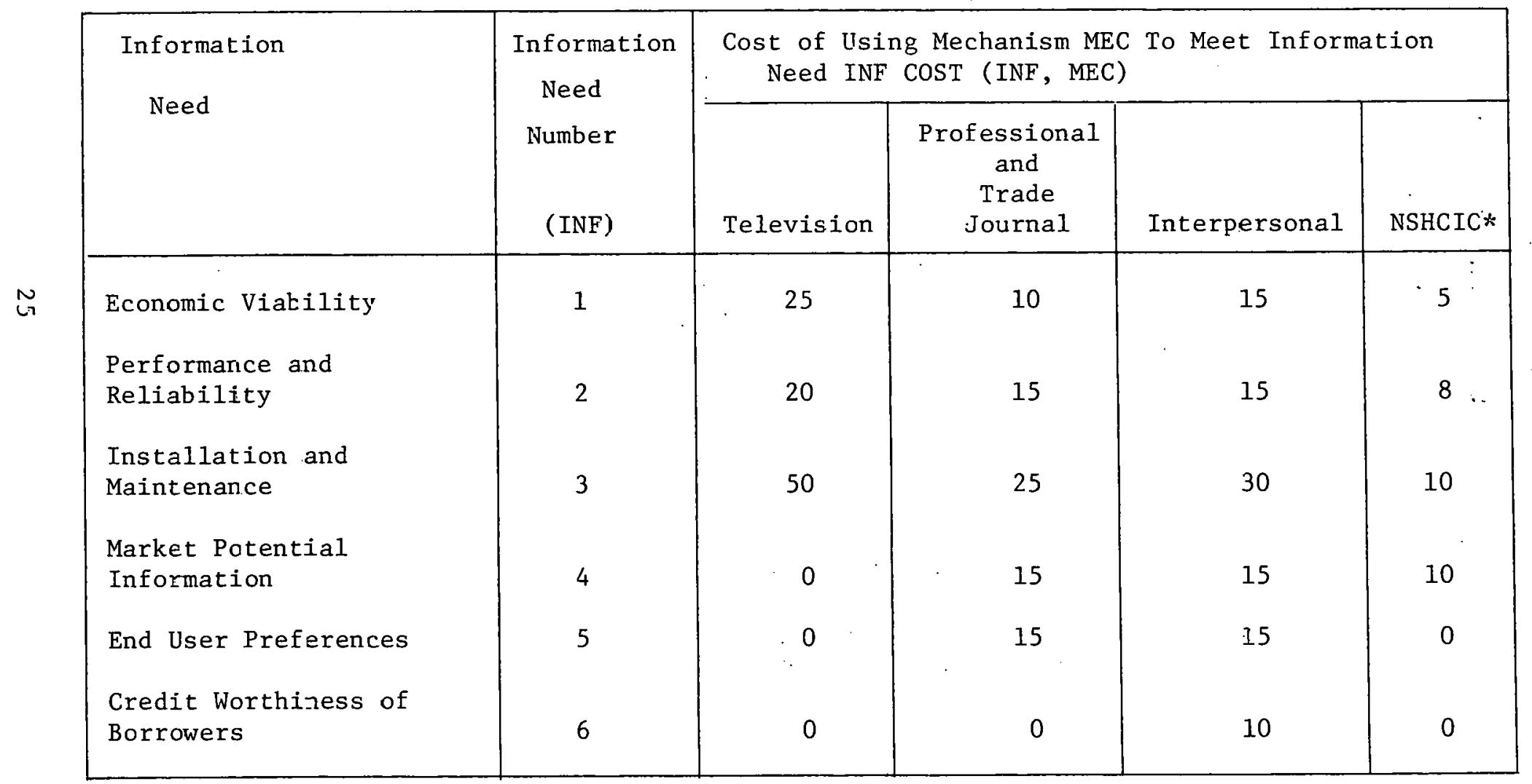

*National Solar Heating and Cooling. Information Center - 
TABLE III-6

PARTICIPANT-TO-PARTICIPANT INFORMATION

TRANSFER EFFECTIVENESS: INPUT ARRAY PTOP (PART 1, PART 2)

\begin{tabular}{|c|c|c|c|c|}
\hline \multicolumn{5}{|c|}{ ARRAY PTOP (PART 1, PART 2) } \\
\hline \multirow{2}{*}{$\begin{array}{l}\text { Assisting } \\
\text { Participant } \\
\text { (PART 1) }\end{array}$} & \multicolumn{4}{|c|}{$\begin{array}{c}\text { Participant-to-Participant } \\
\text { Trals[ei Effectiveness } \\
\text { (Part 2) }\end{array}$} \\
\hline & 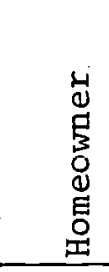 & 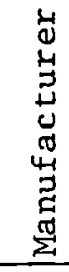 & 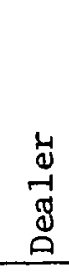 & 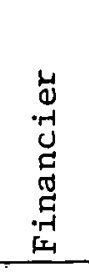 \\
\hline Homeowner & 0 & .1 & .1 & .1 \\
\hline Manufacturer & .5 & 0 & .9 & .1 \\
\hline Dealer & .9 & .2 & 0 & .3 \\
\hline Financier & .6 & .1 & .1 & 0 \\
\hline
\end{tabular}




\subsection{Processing of the Example}

\subsubsection{Computation of Primary Benefits}

The principal steps involved in model processing are depicted in Figure 2-2. After reading and storing the input data, actual processing begins with the computation of primary benefits. As was mentioned in Subsection 2.2 , benefits are defined in terms of:

- Percentage of the market that is impacted by satisfying a specific information need of a specific participant.

Primary benefits are those that result when a participant group which receives information uses that information itself. Primary benefits are derived via the following steps:

(a) Conversion of the elements of each row of input array INFIMP (PART, INF) from the 1-5 scale to proportions. This is done by:

- Changing the 1 's in INFIMP (PART, INF) to zeros

- Summing all elements in each row of array INFIMP (PART, INF)

- Dividing each element of each row of INFIMP (PART, INF) by the row sum computed above.

Table III-7 shows array INFIMP (PART, INF) before and after its proportionalization.

(b) Computation of new array RELIMP (PART, INF): Array RELIMP (PART, INF) is the matrix which shows the relative importance of meeting each information need of each participant in terms of impact on the market under investigation. It is assumed that if all needed information is delivered to all participants, then the total market impact is 100 percent. Hence, the sum of all elements in R.LIMP (PART, INF) equals 1.0 . This array is computed as follows:

RELIMP (PART, INF) = PRT IMP (PART) X INFIMP (PART, INF) (normalized to 1.0 )

Array RELIMP (PAR'T, INF) is shown in Table III-8. 
TABLE III-7

CONVERSION OF THE ELEMENTS OF EACH ROW OF INPUT ARRAY INFIMP (PART, INF) FROM THE 1-5 SCALE TO PROPORTIONS

ARRAY INFIMP (PART, INF) EXPRESSED IN TERMS OF 'I'HE 1-5 SCALE

\begin{tabular}{|c|c|c|c|c|c|c|c|}
\hline \multirow[b]{2}{*}{ Participants } & \multirow{2}{*}{$\begin{array}{c}\text { Participant } \\
\text { Number } \\
\text { (PART) }\end{array}$} & \multicolumn{6}{|c|}{ Information Needs } \\
\hline & & $\begin{array}{l}\overrightarrow{0} \\
0 \\
0 \\
0 \\
5 \\
0 \\
0 \\
0 \\
0 \\
0\end{array}$ & 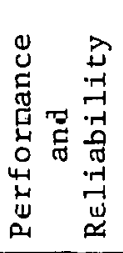 & 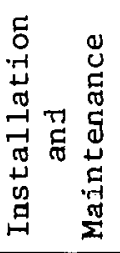 & 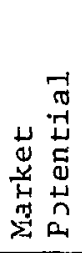 & 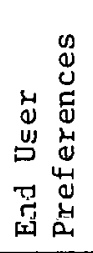 & 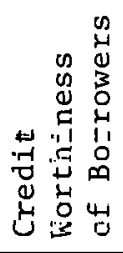 \\
\hline Homeowner & 1 & 5 & 4 & 1 & 1 & 1 & 1 \\
\hline Manufacturer & 2 & 4 & 4 & 4 & 5 & 5 & 1 \\
\hline Dealer & 3 & 3 & 3 & 5 & 4 & 1 & 1 \\
\hline Financier & 4 & 1 & 3 & 1 & 1 & 1 & 5 \\
\hline
\end{tabular}

ARRAY INFIMP (PART, INF) EXPRESSED IN TERMS OF PROPORTIONS

\begin{tabular}{|c|c|c|c|c|c|c|c|}
\hline \multirow[b]{2}{*}{ Participants } & \multirow{2}{*}{$\begin{array}{c}\text { Participant } \\
\text { Number } \\
\text { (PART) }\end{array}$} & \multicolumn{6}{|c|}{ Informat1nn Needs } \\
\hline & & 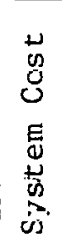 & 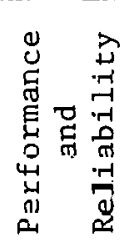 & 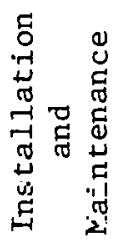 & 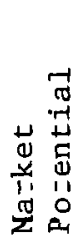 & 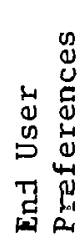 & 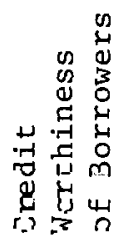 \\
\hline Homeowner & 1 & .56 & .44 & 0 & $u$ & 0 & 0 \\
\hline Manufacturer & 2 & .18 & .18 & .18 & .23 & .23 & 0 \\
\hline Dealer & j & .20 & .20 & .33 & $: 27$ & 0 & 0 \\
\hline Financier & 4 & 0 & .38 & 0 & 0 & 0 & .62 \\
\hline
\end{tabular}


TABLE III-8

COMPUTED ARRAY RELIMP* (PART, INF)

\begin{tabular}{|c|c|c|c|c|c|c|c|}
\hline \multicolumn{2}{|c|}{ Participants } & \multicolumn{6}{|c|}{ Information Needs } \\
\hline $\begin{array}{l}\text { Participants } \\
\text { Category }\end{array}$ & $\begin{array}{c}\text { Participant } \\
\text { Number } \\
\text { (PART) }\end{array}$ & $\begin{array}{l}\Delta \\
0 \\
0 \\
0 \\
\vdots \\
0 \\
\Delta \\
0 \\
2 \\
0\end{array}$ & 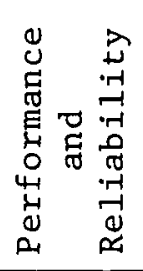 & 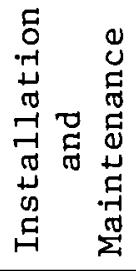 & 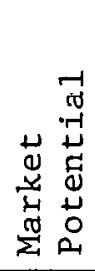 & 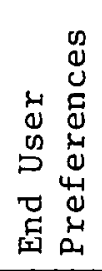 & 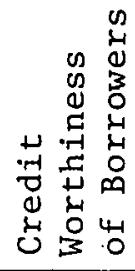 \\
\hline Homeowner & 1 & .33 & .27 & 0 & 0 & 0 & 0 \\
\hline Manufacturer & 2 & .02 & .02 & .02 & .02 & .02 & 0 \\
\hline Dealer & 3 & .04 & .04 & .07 & .05 & 0 & 0 \\
\hline Financier & 4 & 0 & .04 & 0 & 0 & 0 & .06 \\
\hline
\end{tabular}

*Array RELIMP (PART, INF) shows the relative importance of meeting each specific information need "INF" of each participant "PART": normalized to 1.0 
(c) Computation of new array PRIMARY BENEFIT (PART, INF, MEC), where

PRIMARY BENEFIT (PART, INF, MEC) = RELIMP (PART, INF) X MECEFF. (PART, MEC)

(d) Determination of primary benefits and the best information dissemination mechanism for each participant/information need/mechanism combination by finding the mechanisms $\mathrm{MEC}^{+}$ in which

$\left.\frac{\text { PRIMARY BENEFIT (PART, INF, MEC }}{+}\right) \geq \frac{\text { PRIMARY BENEFIT (PART, INF, MEC) }}{\left.\text { COS' (INF, MFF } \Gamma^{+}\right)}$

Table III-9 shows the fullowing for each participant/information need combination:

- Primary benefits

- Best information dissemination mechanisms

- Primary benefit/cost ratio of the best mechanism

- Hypothetical cost of using the best mechanism to satisfy each participant/intormation need combinatiun.

On the basis of Table III-y, and solely with respect to primary benefits, the moot important tasks are getting information to homeowners--the end users of solar systems in the market under investigation.

\subsubsection{Development of Information Chains}

After computing primary benefits, the model develops information thains that definc altcrnative information f1 nw paths and are used to compute secondary benefits. A tree is developed for each participant/information need combination. The trees show all paths over which information needed by a specific participant group can reach that group. 
TABLE III-9

INFOEMATION DISSEMINATION TASKS RANKED ACCORDING TO PRIMARY BENEFIT/COST RATIO

\begin{tabular}{|c|c|c|c|c|c|c|}
\hline $\begin{array}{l}\text { Task } \\
\text { Number }\end{array}$ & Participant & Infornation Need & $\begin{array}{l}\quad \text { Best } \\
\text { Dissemination } \\
\text { Mechanism }\end{array}$ & $\begin{array}{l}\text { Cost of } \\
\text { Best Mechanism } \\
(\$)\end{array}$ & $\begin{array}{l}\text { Primary } \\
\text { Benefit }\end{array}$ & $\begin{array}{l}\text { Primary } \\
\text { Benefit/Cost } \\
\text { Ratio }\end{array}$ \\
\hline 1 & Homeowner & Economic Viability & NSHCIC* & 5,000 & 2.00 & 4.00 \\
\hline 2 & Homeowner & Performance and Reliability & Interpersonal & 15,000 & 4.00 & 2.67 \\
\hline 3 & Financier & Credit Wortíiness & Interpersonal & 10,000 & $0.9 \dot{4}$ & 0.94 \\
\hline 4 & Dealer & Economic Viability & NSHCIC & 5,000 & 0.24 & 0.48 \\
\hline 5 & Manufacturer & Economic Viability & $\begin{array}{l}\text { Professional and } \\
\text { Trade Journals }\end{array}$ & 10,000 & 0.44 & 0.44 \\
\hline 6 & Dealer & Market Potential & Interpersonal & 15,000 & 0.64 & 0.43 \\
\hline 7 & Dealer & Installation and Maintenance & NSHCIC & 10,000 & 0.40 & 0.40 \\
\hline 8 & Financier & Performance and Reliability & Interpersonal & 15,000 & 0.56 & 0.38 \\
\hline 9 & Manufacturer & Market Potential & $\begin{array}{l}\text { Professional and } \\
\text { Trade Journals }\end{array}$ & 15,000 & 0.55 & 0.36 \\
\hline 10 & Manufacturer & End User Preferences & $\begin{array}{l}\text { Professional and } \\
\text { Trade Journals }\end{array}$ & 15,000 & 0.55 & 0.36 \\
\hline 11 & Dealer & Performance and Reliability & Interpersonal & 15,000 & 0.48 & 0.32 \\
\hline 12 & Manufacturer & Performance and Reliability & $\begin{array}{l}\text { Professional and } \\
\text { Trade Journals }\end{array}$ & 15,000 & 0.44 & 0.29 \\
\hline 13 & Manufacturer & Installation and Maintenance & $\begin{array}{l}\text { Professional and } \\
\text { Trade Journals }\end{array}$ & 25,000 & 0.44 & 0.18 \\
\hline
\end{tabular}

*National So:ar Heating and Cooling Information Center 
In the example, there are four participants. Each has between two and five information needs. Collectively, there are 13 participant/information needs combinations. For each combination, the model develops one or more chains. The number of chains generated is a function of the number of participant categories from which the subject participant can acquire the informalion. Figure 3-1 ohows the shains assnciated with the delivery of "economic viability" and "performance and reliability" information to homeowners. It indicates, for example, that their are three paths for conveying "economic viability" information to homeowners. Homeowners can obtain such information from:

- The manufacturer

- The NSHCIC--which obtains it from the manufacturer

- The solar equipment dealer--who also obtains the information from the manufacturer.

On the basis of Figure 3-1, one can conclude that:

- There are multiple paths over which homeowners can obtain solar-related information

- Manufacturers are the ultimate sources of the solar-related information disseminated to homeowners.

\subsubsection{Computation of Secondary Benefits}

As discussed in Subsection 2.2, secondary benefits are those that accrue to a participant group when it passes information received (or generated) to other groups. In the present example, secondary benefits arise in two cases: 
INFORMATION CHAINS FOR CONVEYING "ECONOMIC VIABILITY" INFORMATION TO HOMEOWNERS

Chain (a)

Manufacturer $\rightarrow$ Homeowner

Chain (b)

Manufacturer $\rightarrow$ NSHCIC $\rightarrow$ Homeowner

Chain (c)

Manufacturer $\rightarrow$ Dealer $\rightarrow$ Homeowner

INFORMATION CHAINS FOR CONVEYING "PERFORMANCE AND RELIABILITY"

INFORMATION TO HOMEOWNERS

Chain (a)

Manufacturer $\rightarrow$ Homeowner

Chain (b)

Manufacturer $\rightarrow$ Dealer $\rightarrow$ Homeowner

FIGURE 3-1

EXAMPLES OF INFORMATION CHAINS DEVELOPED BY THE MITRE SOLAR INFORMATION PROCESS MODEL 
- Case A: information is passed directly to another participant group which needs it. For example, referring to Figure 3-1, Case A secondary benefits accrue to manufacturers by disseminating "performance and reliability" information to homeowners.

- Case B: information is used by the participant group, along with other information/data, to compute an item of information needed by another group, and then convey the new information to the other group. For example, referring to Figure 3-1, manufacturers use "system cost" and "performance and reliability" information to develop "economic viability" information. Hence, Case B secondary benefits accrue to manufacturers as a result of their developing "economic viability" information and disseminating it to homeowners.

Quantitatively, the Case A secondary benefits which accrue to participant group PARTl, which passes information item INFl to participant group PART2, are given by the equation

SECONDARY BENEFIT (PART1, INF1) = RELIMP (PART2, INF1) $\mathrm{X}$ PTOP (PART1, PART2) X MECEFF (PART1, MEC ${ }^{+}$)

where $\mathrm{MEC}^{+}$is the best mechanism for conveying information need INFI to participant group PART1.

With respect to Case $B$, let INFl denote an item of information needed by participant PART 1 that is used to compute information item INF2 to be conveyed to participant PART2. In addition, let $\mathrm{N}$ be the total number of information items needed by participant PARTl to compute INF2. Then the Case B secondary benefits that accrue from delivering information item INFl to participant PARTl are given by SECONDARY BENEFIT (PART1, INF1) = RELIMP (PART1, INF2) $\mathrm{X}$ PTOP (PART1, PART2) X MECEFF (PART1, INF1) $\times 1 / \mathrm{N}$

Table III-10 shows--in rank order--the secondary benefits which accrue to participants in the example, and indicates that only 
TABLE IIT- 10

RANK-ORDERED LISTING OF THE SECONDARY BENEFITS ACCRUING TO PARTICIPANTS IN THE SAMPLE PROBLEM

\begin{tabular}{|c|c|c|c|c|}
\hline Task & Participant & Information Need & $\begin{array}{l}\text { Primary } \\
\text { Benefit }\end{array}$ & $\begin{array}{l}\text { Secondary } \\
\text { Benefit }\end{array}$ \\
\hline 1 & Manufacturer & Economic Viability & 0.44 & 4.00 \\
\hline 2 & Manufacturer & Performance and Reliability & 0.44 & 3.29 \\
\hline 3 & Dealer & Performance and Reliability & 0.48 & 3.01 \\
\hline 4 & Dealer & Economic Viability & .24 & 1.80 \\
\hline 5 & Manufacturer & Installation and Maintenance & 0.44 & 1.44 \\
\hline 6 & Manufacturer & Market Potential & 0.55 & 1.15 \\
\hline 7 & Homeowner & Economic Viability & 2.00 & 0.00 \\
\hline 8 & Homeowner & Performance and Reliability & 4.00 & 0.00 \\
\hline 9 & Manuíacturer & End User Preferences & 0.55 & 0.00 \\
\hline 10 & Dealer & Installation and Maintenance & 0.40 & 0.00 \\
\hline 11 & Dealer & Market Potentia1 & 0.64 & 0.00 \\
\hline 12 & Financier & Performance and Reliability & 0.56 & 0.00 \\
\hline 13 & Financier & Credit Worthiness & 0.94 & 0.00 \\
\hline
\end{tabular}


manufacturers and dealers receive secondary benefits. They are the only participants which process and disseminate information to others. Homeowners and financiers are end users--rather than processors or disseminators--of information. Hence, they receive no secondary benefits.

According to Table III-10, the participant/information need cumbination leading to the greatest quantity of occondary benefits is "provision of economic viability information to manufacturers." As Figure 3-1 shows, manufacturers--the generators of this information item--disseminate it to:

- Homeowners

- Dealers, who subsequently disseminate it to homeowners. Secondary benefits accrue to manufacturers in both cases.

\subsubsection{Computation of Total Benefits and Total Benefit/Cost Ratio}

After calculating the primary and secondary henefits for each. participant/information need sombination, the mulel develops total benefits and the total benefit/cost ratio. Total benefits are the sum: of the primary and secondary benefits. The total benefit/cost ratio for each participant/information need combination is the total benefit divided by the cost of the best information dissemination mechanism:

Total Benefit/Cost Ratio $=\frac{\text { Primasy Bencifit }+ \text { Secondary Benefle }}{\text { Cost of Best Mechanism }}$ Total benefit and total benefit/cost ratio are the indices used in the model for establishing priorities. 
Table III-11 shows the 13 participant/information need combinations in the example ranked according to total benefit/cost ratio. In addition, Table III-11 shows:

- Primary benefit

- Secondary benefit

- Total benefit

- Best information dissemination mechanism

- Cost associated with using the best mechanism.

\subsection{Results and Conclusions from the Sample Application}

Table III-11 summarizes SIP model outputs for the foregoing examples marker example, from which the following conclusions may be drawn:

- Using total benefit/cost ratio as the criterion, the most important information tasks are to:

- Provide manufacturers with "economic viability" information

- Provide solar equipment dealers with "economic viability" information.

- The most important participant in the overall functioning of this market is the homeowner. However, the most important information tasks are to satisfy the information needs of the participants to whom homeowners go for information-manufacturers and dealers.

- If costs are ignored and total benefit--rather than total benefit/cost ratio--is used as the basis for establishing priorities, the most important tasks are to supply:

- Manufacturers with "economic viability" information

- Homeowners with "performance and reliability" information.

- Manufacturers and dealers, in addition to being end users of information, generate, package and disseminate information to others. Hence they accrue primary and secondary benefits. 
TABLE III-11

MITRE SOAAZ INFORMETION PROCESS MODEL OUTPUT:

PARTIC IPANT/INFORMATION DEפD LASKS RANKED ACCORDING TO TOTAL BENEFIT/CCST RATIC

\begin{tabular}{|c|c|c|c|c|c|c|c|c|}
\hline Task & Participant & Inf Jrmat Lon Need & $\begin{array}{l}\text { BEST INFORMATION } \\
\text { IISSEMINATION MECHANISM }\end{array}$ & $\begin{array}{l}\text { Primary } \\
\text { Benefit }\end{array}$ & $\begin{array}{l}\text { Secordary } \\
\text { Benef } 1 \mathrm{t}\end{array}$ & $\begin{array}{l}\text { Total } \\
\text { Eenefit }\end{array}$ & $\begin{array}{l}\operatorname{Cos} t * * \\
(\$)\end{array}$ & $\begin{array}{l}\text { Total Benefit/ } \\
\text { Cost Ratio }\end{array}$ \\
\hline 1 & Manufacturer & Ec.onomic Jability & Profesionial ard Trade Journal & 0.44 & 4.60 & 4.44 & 10,000 & 4.44 \\
\hline 2 & Dealer & Economdc JiabiLt: & Inte:personal & 0.24 & ¿. $\varepsilon_{0}$ & 2.04 & 15,000 & 4.08 \\
\hline 3 & Homeowner & Econonde Viabiliti & NSHCiC* $*$ & 2.00 & 0.00 & 2.00 & 5,000 & 4.00 \\
\hline 4 & Homeowner & Performance and Relfability & Interpersonal & 4.00 & 0.00 & 4.00 & 15,000 & 2.67 \\
\hline 5 & Manufacturer & Performance andl Relfability & Prafesslonal and Trade Journal & 0.44 & 3.29 & 3.73 & 15,000 & 2.48 \\
\hline 6 & Dealer & Performance and Relfability & Interpersonal. & 0.48 & 3.02 & 3.50 & 15,000 & 2.33 \\
\hline 7 & Manufacturer & Market Posentig:I & Professional and Trade Joumal & 0.55 & 1.15 & 1.70 & 15,000 & 1.13 \\
\hline 8 & Financier & Credit Worthiness of Borrowers & Inte:personal & 0.94 & 0.00 & 0.94 & 10,000 & 0.94 \\
\hline 9 & Manufacturer & Installation and laintenance & Professional and Trade Journal & 0.44 & 1.44 & 1.88 & 25,000 & 0.75 \\
\hline 10 & Dealer & Market Potential & Interpersonal & 0.64 & 0.00 & 0.64 & 15,000 & 0.43 \\
\hline 11 & Dealer & Installation and MaIntenance & NSECLCLC & 0.40 & 0.00 & 0.40 & 10,000 & 0.40 \\
\hline 12 & Financier & Performance and Rellability & Interpersonal & 0.56 & 0.00 & 0.56 & 15,000 & 0.38 \\
\hline 13 & Manufacturer & End User Prefemences & Professional and Trade Journal & 0.55 & 0.00 & 0.55 & 15,000 & 0.36 \\
\hline
\end{tabular}

* National Solar Heatirg and Cool1rg Lnformaticn Center.

**Cost to the Federal government in using each mechan 1sr. 
- Homeowners and financiers are end users of information. Hence, the total benefits which accrue to them consist entirely of primary benefits.

- As Figure 3-1 shows, there are typically multiple paths over which end users of information can acquire it.

- Since satisfying a specific information need of a specific participant involves information development, packaging and dissemination activities by other participants, the market is characterized by the passing of information between participants who are not the ultimate end users of that information. Hence, the total benefits consist primarily of secondary benefits.

3.4 Examples of Using MITRE Solar Information Process Model Results to Formulate Information Outreach Initiatives

The participant/information need priorities, as listed in Table III-11, are a basis for:

- Formulating market-specific information outreach initiatives

- Assigning priorities to initiatives.

Thus, in the foregoing example, analysis of decisionmaking and information processes in the one and two family homes retrofit market for solar water heaters shows that the homeowner is the key participant. Homeowners, as part of their decisionmaking process, require "economic viability" information--information which they obtain ultimately from manufacturers, as Figure 3-1 shows. Hence, of highest priority is the requirement for a Government solar information outreach initiative to:

- Appraise manufacturers of methods whereby homeowners determine "economic viability"

- Provide manufacturers with (or assist them to collect) the specific items of information needed to determine economic viability--focussing on those items which are difficult for manufacturers to obtain without Federal assistance. 
Similarly, analysis of the functioning of the subject market shows that dealers--who typically function as retailers, installers and maintainers--are an intermediary between the two strategic participants: homeowners and manufacturers. As Table III-11 shows, tasks of high priority are to convey "economic viability" and "performance and reliability" information to dealers--information which they obtain from manufacturers and disseminate to homeowners. According to Table III-11, the optimum means for conveying such information to dealers is person-to-person. This indicates the need for a further, marketspecific outreach initiative:

- Sponsor a series of workshops which bring solar manufacturers and dealers together to:

- Convey "economic viability" and "performance and reliability" information to dealers

= Provide fepthask. to manufacturers regarding equipmentrelated problems that dealers are experiencing.

By combining the results obcained from analyzing decisionmaking and information processes in the market with model results, it is possible to formulate other information outreach initiatives as was done above. 
4.0 ANALYSIS OF INFORMATION PROCESSES IN SOLAR MARKETS: RESULTS AND CONCLUSIONS

This Section summarizes the findings and conclusions that resulted from applying the MITRE Solar Information Process Model to the analysis of information processes in the solar markets relating to water and space in residences and commercial buildings and agricultural process heat applications.

- With respect to information processes, each market participant can be characterized in terms of one or more of the following functional attributes:

- Information/data generator

- Information end user

- Information packager/repackager

- Information disseminator

Tables IV-1 and IV-2 show the characteristic information process functions of participant groups within the buildings and agricultural process heat markets, respectively.

- Tables IV-3 through IV-8 show the fifteen most important participant information-need combinations, using total benefits (see Subsection 2.2.2) as the measure of importance, in each market (or group of markets):

- New one-and-two-family-homes market (custom construction): Table IV-3

- New one-and-two-family-homes market (speculative construction): Tablc IV-4

- New mobile-homes market: Table IV-5

- One-and-two-family-homes retrofit market (including mobile homes): Table IV-6

- Commercial-building market (new and retrofit): Table IV-7

- Agricultural-process-heat market (rational and traditional farms): Table IV-8.

These tables show the participant groups' information needs which must be satisfied before subsequent information needs can be met. 
Table IV-9 1ists the principal decision makers in each market. Comparison with Tables IV-3 through IV-8, indicates that, in general, the information needs to be satisfied first are not those of these principal decision makers, but those of entities from which principal decision makers obtain their information: Federal system/ integration agencies and manufacturers.

- In both the buildings and APH markets, Federal system/ integration agencies (e.g., DOE, USDA, etc.) and solar manufacturers serve as the ultimate sources of information for all other participant groups.

- Solar/equipment manufacturers and Federal system/integration agencies, the ultimate sources of information for the principal decision makers and other participants, obtain information for their own use and for dissemination to others by

- generating it themselves

- obtaining it from the R\&D community

- R\&D performers and solar equipment manufacturers are the major generators of

- Solar/system/engineering, performance, and reliability in formation

- Solar/system/installation and maintainability information

- Marketing-research information

-- End-user desires and preferences

-- Market Assessment

-- Market demographics

- A\&E firms, architects, mechanical engineers, mechanical contractors and energy and conservation consultants function not only as end users of Informalium, but also ao oourses of information for

- Developers

- Homeowners

- Farmers

- Mobile home manufacturers

- Financiers

- Since satisfying a particular information need of a particular participant involves information generation, packaging, and dissemination activities by other participants, the buildings and APH markets are characterized by the passing of 
information between participants who are not the ultimate users of that information. Hence, in the general case, the total benefits resulting from meeting each information need consist primarily of secondary benefits.

- There are a multiplicity of paths over which end users of information can acquire it. These paths are not necessarily equally efficient. Since end users of information utilize sources in which they have the most confidence, the objective should be to identify "optimum" information paths, but rather to insure that, whatever information source end users go to, the information that they need is there.

- Significant benefits (especially secondary benefits) accrue when the information needs of state and local government agencies (e.g., Tax Assessment Agencies, Consumer Protection Agencies, etc.) are satisfied, since these entities are perceived as sources of information by homeowners, farmers, and other decision makers. This is especially true of information relating to:

- Qualified installers

- Building codes and solar-related ordinances

- Property taxes

- Resale values. 
TABLE IV -1

SOLAR INFORMATION PROCESS FUNCTIONS OF PARTICIPANT GROUPS WITHIN BUILDING MARKETS

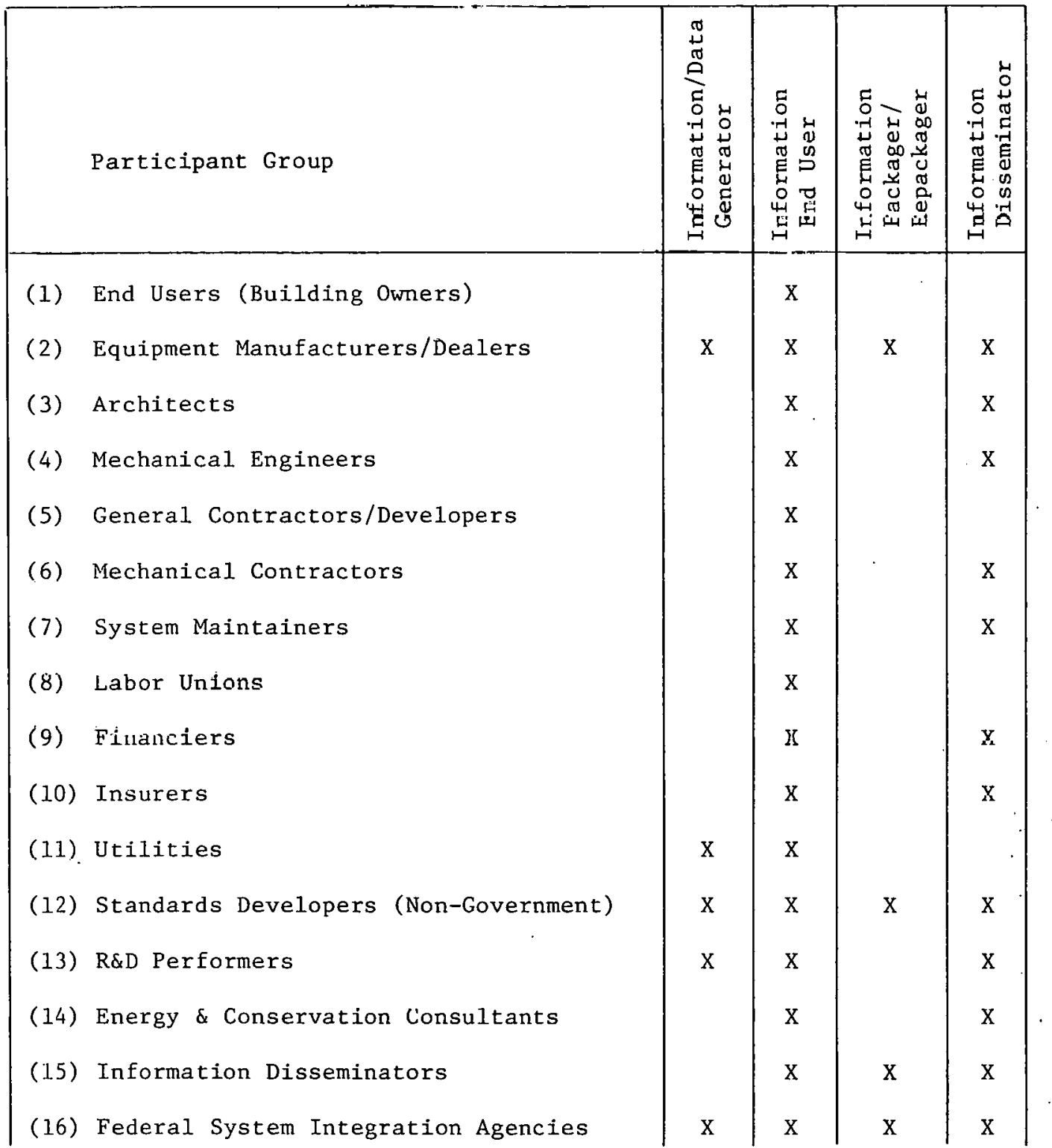


TABLE IV-1 (Concluded)

SOLAR INFORMATION PROCESS FUNCTIONS OF PARTICIPANT GROUPS WITHIN BUILDING MARKETS

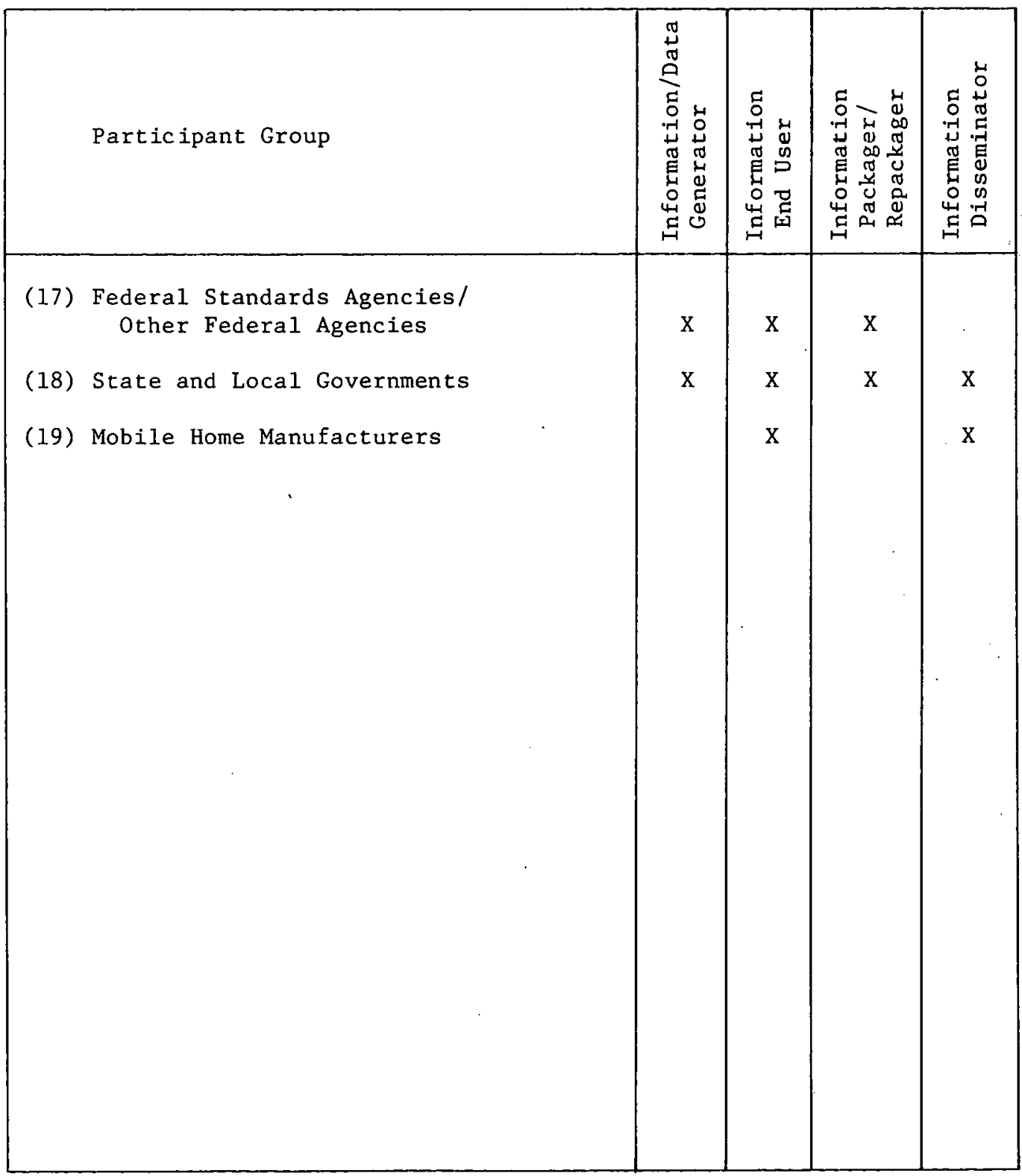


SOLAR INFORMATION PROCESS FUNCTIONS OF PARTICIPANT GROUPS WITHIN THE AGRICULTURAL PROCESS HEAT MARKETS

\begin{tabular}{|c|c|c|c|c|c|}
\hline & Participant Group & 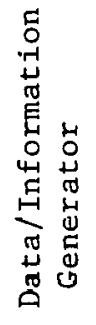 & 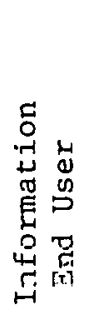 & 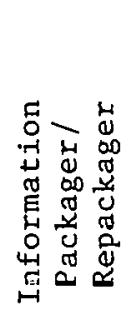 & 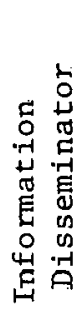 \\
\hline (1.) & Ender Users (Farmers and Ranchers) & & $\mathrm{x}$ & & \\
\hline (2) & $\begin{array}{l}\text { Solar Manufacturers and Dealers } \\
\text { - Manufacturers } \\
\text { Dealers }\end{array}$ & $\mathrm{x}$ & $\begin{array}{l}\mathrm{X} \\
\mathrm{X}\end{array}$ & $\mathrm{x}$ & $\begin{array}{l}\mathrm{x} \\
\mathrm{x}\end{array}$ \\
\hline (3) & A\&E Firms & & $\mathrm{x}$ & & $\mathrm{x}$ \\
\hline (4) & General Contractors & & $\mathrm{x}$ & & \\
\hline (b) & Mechanical Contractors & & $\mathrm{x}$ & & $\mathrm{x}$ \\
\hline (6) & Solar System Maintainers & & $\mathrm{x}$ & & $\mathrm{x}$ \\
\hline (7) & Financiers & & $\mathrm{x}$ & & $\mathrm{Y}$ \\
\hline (8) & Insurers & & $\mathrm{x}$ & & $\mathrm{x}$ \\
\hline (9) & Uti.1ities & & $\mathrm{x}$ & & \\
\hline (10) & Non-Government Standards Developers & $\mathrm{x}$ & $\mathrm{x}$ & $\mathrm{x}$ & $\mathrm{x}$ \\
\hline (11) & R\&D Performers & $\mathrm{x}$ & $\mathrm{x}$ & $\mathrm{x}$. & $\mathrm{x}$ \\
\hline$(12)$ & Information Disseminators & & $x$ & $\mathrm{x}$ & $\mathrm{x}$ \\
\hline (13) & Federal System Integration Agencies & $\mathrm{x}$ & $\mathrm{x}$ & $\mathrm{x}$ & $\mathrm{x}$ \\
\hline (14) & $\begin{array}{c}\text { Federal Standards Agencies/ } \\
\text { Other Federal Agencies }\end{array}$ & $\mathrm{x}$ & $\mathrm{X}$ & $\mathrm{x}$ & $\mathrm{x}$ \\
\hline (15) & State and Local Governments & $\mathrm{x}$ & $\mathrm{x}$ & $\mathrm{x}$ & $\mathrm{x}$ \\
\hline
\end{tabular}


TABLE IV-3

THE MOST IMPORTANT INFORMATION NEEDS OF PARTICIPANT GROUPS, RANKED IN TERMS OF TOTAL BENEFITS (NEW ONE- AND TWO-FAMILY HOMES MARKET: CUSTOM CONSTRUCTION)

\begin{tabular}{|c|c|c|c|c|}
\hline & Participant Group & Solar-Specific Information Need & $\begin{array}{c}\text { Are the } \\
\text { Needs } \\
\text { Adequately } \\
\text { Met }\end{array}$ & $\begin{array}{c}\text { Federal } \\
\text { STT } \\
\text { Assistance } \\
\text { Necessary }\end{array}$ \\
\hline (1) & Solar manufacturers and dealers & $\begin{array}{l}\text { System design and performance } \\
\text { information }\end{array}$ & No & Yes \\
\hline (2) & $\begin{array}{l}\text { Federal system integraticn } \\
\text { agencies }\end{array}$ & $\begin{array}{l}\text { Lists of qualified installers and } \\
\text { maintainers }\end{array}$ & No & Yes \\
\hline (3) & Solar manufacturers and dealers & $\begin{array}{l}\text { System installation and mainte- } \\
\text { nance information }\end{array}$ & No & Yes \\
\hline (4) & $\begin{array}{l}\text { Federal system integration } \\
\text { agencies }\end{array}$ & $\begin{array}{l}\text { System design and performance } \\
\text { information }\end{array}$ & No & Yes \\
\hline (5) & Solar manufacturers and dəalers & $\begin{array}{l}\text { Lists of qualified installers and } \\
\text { maintainers }\end{array}$ & No & Yes \\
\hline (6) & Solar manufacturers and dealers & Market potential information & No & Yes \\
\hline (7) & $\begin{array}{l}\text { Federal system integration } \\
\text { agencies }\end{array}$ & $\begin{array}{l}\text { System installation and mainte- } \\
\text { nance information }\end{array}$ & No & Yes \\
\hline (8) & State and local governments & $\begin{array}{l}\text { Lists of qualified installers and } \\
\text { maintainers }\end{array}$ & No & Yes \\
\hline
\end{tabular}


TABLE IV-3 ( Concluded)

THE MOST IMPORT:INT INFCRMATION NEEDS OF PARTICIPANT GROUPS, PANKED IN TERMS OF TOTAL BENEFITS (NEW ONE- AND TWO-FAMILY HOMES MARKET: CUSTOM CONSTRUCTION)

\begin{tabular}{|c|c|c|c|c|}
\hline . & Participant Group & Solar-Spezific Information Need & $\begin{array}{c}\text { Are the } \\
\text { Neecs } \\
\text { Adequitely } \\
\text { Met }\end{array}$ & $\begin{array}{c}\text { Federal } \\
\text { STT } \\
\text { Assistance } \\
\text { Necessary }\end{array}$ \\
\hline (9) & $\begin{array}{l}\text { Federal system integration } \\
\text { agencies }\end{array}$ & Tax incentives & Yes & \\
\hline (10) & $\begin{array}{l}\text { Federal system integration } \\
\text { agencies }\end{array}$ & Demonstration program results & No & Yes \\
\hline (11) & Homeowners & $\begin{array}{l}\text { Lists of qualified installers anc } \\
\text { maintainers }\end{array}$ & No. & Yes \\
\hline (12) & Homeowners & Lists of qualified designers & $\mathrm{Na}$ & Yes \\
\hline (13) & Homeowners & Tax incenzives & Yes & \\
\hline (14) & Homeowners & Spstem cost information & Yes & \\
\hline (15) & Homeowners & Eronomic viability information & No & Yes \\
\hline
\end{tabular}

SOURCE: MITRE SIP Model 
TABLE IV -4

THE MOST IMPORTANT INFORMATION NEEDS OF PARTICIPANT GROUPS, RANKED IN TERMS OF TOTAL BENEFITS (NEW ONE- AND TWO-FAMILY HOMES MARKET: SPECULATIVE CONSTRUCTION)

\begin{tabular}{|c|c|c|c|c|}
\hline & Participant Group & Solar-Specific Information Need & $\begin{array}{c}\text { Are the } \\
\text { Needs } \\
\text { Adequately } \\
\text { Met } \\
\end{array}$ & $\begin{array}{c}\text { Federa1 } \\
\text { STT } \\
\text { Assistance } \\
\text { Necessary }\end{array}$ \\
\hline (1) & Solar manufacturers and dealers & $\begin{array}{l}\text { System installation and mainte- } \\
\text { nance information }\end{array}$ & No & Yes \\
\hline (2) & Soilar manufacturers and dealers & $\begin{array}{l}\text { System design and performance } \\
\text { information }\end{array}$ & No & Yes \\
\hline (3) & $\begin{array}{l}\text { Fecieral system integration } \\
\text { agencies }\end{array}$ & $\begin{array}{l}\text { System installation and mainte- } \\
\text { nance information }\end{array}$ & No & Yes \\
\hline (4) & $\begin{array}{l}\text { Federal system integration } \\
\text { agencies. }\end{array}$ & $\begin{array}{l}\text { System design and performance } \\
\text { information }\end{array}$ & No & Yes \\
\hline (5) & Mechanical engineers & $\begin{array}{l}\text { System design and performance } \\
\text { information }\end{array}$ & No & Yes \\
\hline (6) & Mechanical engineers & $\begin{array}{l}\text { System installation and mainte- } \\
\text { nance information }\end{array}$ & No & Yes \\
\hline (7) & $\begin{array}{l}\text { Federal system integration } \\
\text { agencies }\end{array}$ & $\begin{array}{l}\text { Lists of qualified installers and } \\
\text { maintainers }\end{array}$ & No & Yes \\
\hline (8) & Solar manufacturers and dealers & $\begin{array}{l}\text { Lists of qualified installers and } \\
\text { maintainers }\end{array}$ & No & Yes \\
\hline
\end{tabular}


TABLE IV-4 (Concluded)

THE MOST IMPORTANT INFORMATION NEEDS JF ?ARTICIPANT GROUPS, RANKED IN TERME OF TOTAL BENEFITS (NEW ONE- AND IWO-FAMLY TOMES MARRET: SPECULATIVE CONSTRUC.TION)

\begin{tabular}{|c|c|c|c|c|}
\hline & Participant Groups & So-ar-Spæcific Information Need & $\begin{array}{c}\text { Are the } \\
\text { Needs } \\
\text { Ad } \in \text { quately } \\
\text { Met }\end{array}$ & $\begin{array}{c}\text { Federal } \\
\text { STT } \\
\text { Assistance } \\
\text { Necessary }\end{array}$ \\
\hline (9) & $\begin{array}{l}\text { Federal sy } \leqq \text { tem integration } \\
\text { agencies }\end{array}$ & E=snomic viability information & No & Yes \\
\hline (10) & $\begin{array}{l}\text { Federal system integration } \\
\text { agencies }\end{array}$ & Tax incentives & Yes & \\
\hline (11) & $\begin{array}{l}\text { Federal system integration } \\
\text { agencies }\end{array}$ & End user preferences & No & Yes \\
\hline (12) & Solar mancíacturers and dealers & Merket potential information & No & Yes \\
\hline (13) & $\begin{array}{l}\text { Federal system integration } \\
\text { agencies }\end{array}$ & Irvestment requirements & No & Yes \\
\hline (14) & Mechanicai contractors & $\begin{array}{l}\text { Swstem installation and mainte- } \\
\text { rance information }\end{array}$ & No & Yes \\
\hline (15) & $\begin{array}{l}\text { Federal system integration } \\
\text { agencies }\end{array}$ & Demonstration program results & No & Yes \\
\hline
\end{tabular}

SOURCE: MITRE SIP MOdel 
TABLE IV-5

THE MOST IMPORTANT INFORMATION NEEDS OF PARTICIPANT GROUPS, RANKED IN TERMS OF TOTAL BENEFITS (NEW MOBILE HOMES MARKET)

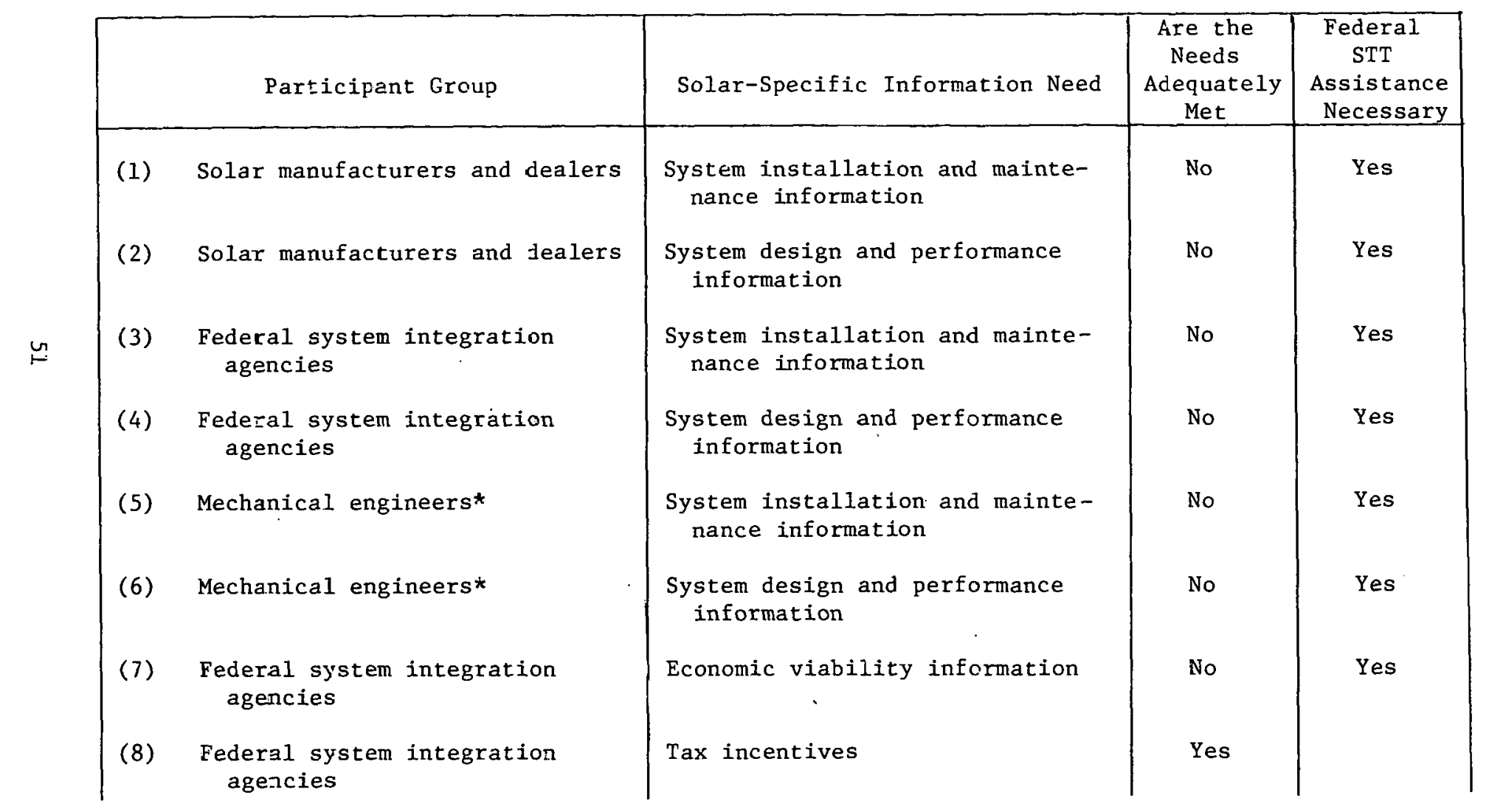


TA3LE IV-5 (Concluded)

THE MOST IMPORTANT INFORMATION NEEDS OF PAFTICIPANT GROUPS, RANKED IN, TERMS OF TOTAL BENEFITS (NEW YOBILE HOMES MARKET)

\begin{tabular}{|c|c|c|c|c|}
\hline & Participant Group & Solar-Specific Information Neet & $\begin{array}{l}\text { Are the } \\
\text { Needs } \\
\text { f.dequately } \\
\text { Get }\end{array}$ & $\begin{array}{l}\text { Federal } \\
\text { STT } \\
\text { Assistance } \\
\text { Necessary }\end{array}$ \\
\hline (9) & $\begin{array}{l}\text { Federal system integration } \\
\text { agencies }\end{array}$ & Demonstration program results & म10 & Yes \\
\hline (10) & $\begin{array}{l}\text { Federal system integration } \\
\text { agencies }\end{array}$ & $\begin{array}{l}\text { End user preferences and } \\
\text { requirements }\end{array}$ & No & Yes \\
\hline (11) & $\begin{array}{l}\text { Federal system iategration } \\
\text { agencies }\end{array}$ & Market potential information & Nio & Yes \\
\hline (12) & Mechanice1 engin三ers= & Economic viability information & No & Yes \\
\hline (13) & Mobile home manufacturers & $\begin{array}{l}\text { System installation and mainte- } \\
\text { nance information }\end{array}$ & No & Yes \\
\hline (14) & Mobile home manufactire:s & Investment requirements & No & Yes \\
\hline (15) & Mobile home manufact & $\begin{array}{l}\text { System design and performance } \\
\text { information }\end{array}$ & No & Yes \\
\hline
\end{tabular}

SOURCE: MITRE SIP. Model 
TABLE IV- 6

THE MOST IMPORTAINT INFORMAZION NEEDS OF PARTICIPANT GROUPS, RANKED IN TERMS OF TOTAL BENEFITS (ONE- AND TWO-FAMILY HOMES RETROFIT MARKET, INCLUDING MOBILE HOMES)

\begin{tabular}{|c|c|c|c|c|}
\hline & Participant & Solar-Specific Information Need & $\begin{array}{c}\text { Are the } \\
\text { Needs } \\
\text { Adequately } \\
\text { Met } \\
\end{array}$ & $\begin{array}{c}\text { Federal } \\
\text { STT } \\
\text { Assistance } \\
\text { Necessary } \\
\end{array}$ \\
\hline (1) & Solar manufacturers and dealers & $\begin{array}{l}\text { System installation and mainte- } \\
\text { nance information }\end{array}$ & No & Yes \\
\hline (2) & Solar manufacturers and dealers & $\begin{array}{l}\text { System design and performance } \\
\text { information }\end{array}$ & No & Yes \\
\hline (3) & $\begin{array}{l}\text { Federal system integration } \\
\text { agencies }\end{array}$ & $\begin{array}{l}\text { Lists of qualified installers and } \\
\text { maintainers }\end{array}$ & No & Yes \\
\hline (4) & Solar manufacturers and dealers & $\begin{array}{l}\text { Lists of qualified installers and } \\
\text { maintainers }\end{array}$ & No & Yes \\
\hline (5) & $\begin{array}{l}\text { Federal system integration } \\
\text { agencies }\end{array}$ & $\begin{array}{l}\text { System design and performance } \\
\text { information }\end{array}$ & No & Yes \\
\hline (6) & $\begin{array}{l}\text { Federal system integration } \\
\text { agencies }\end{array}$ & $\begin{array}{l}\text { System installation and mainte- } \\
\text { nance information }\end{array}$ & No & Yes \\
\hline (7) & $\begin{array}{l}\text { Federal system integration } \\
\text { agencies }\end{array}$ & Tax incentives & Yes & \\
\hline (8) & State and local governments & $\begin{array}{l}\text { Lists of qualified installers and } \\
\text { maintainers }\end{array}$ & No & Yes \\
\hline
\end{tabular}


TABL IV IV (Concluded)

THE MOST IMPORTANT INFORMATION NEEDS OF PARTICIPANT GROUPS, RANKED IN TERMS OF TOTAL BENEFITS (JNE- AND TWC-FAMILY HOMES RZTROFIT MARKET, INCLUDING MOEILE HOMES)

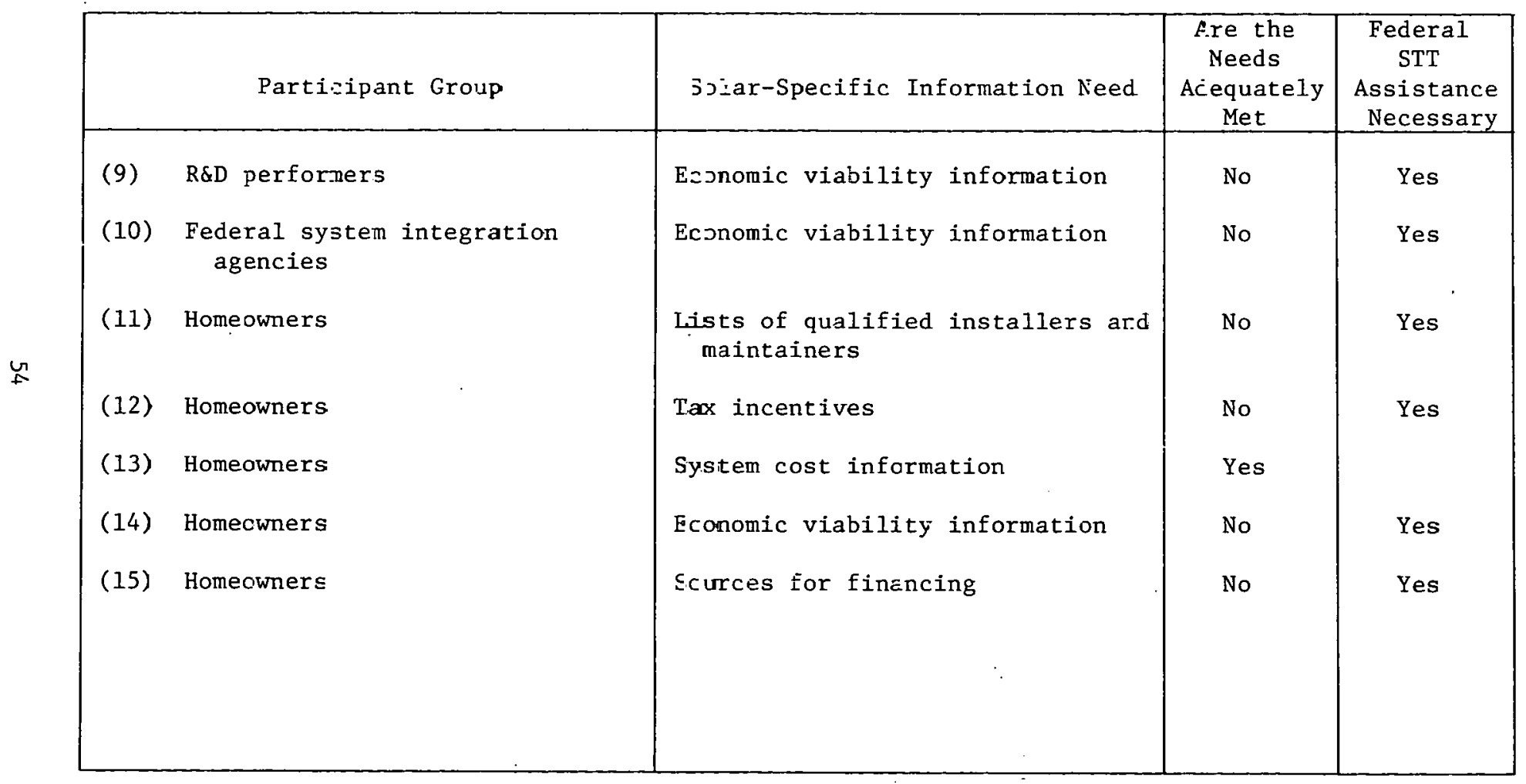

SOURCE: MITRE SIP Mode1 
TABLE IV -7

THE MOST IMPORTANT INFORMATION NEEDS OF PARTICIPANT GROUPS, RANKED IN TERMS OF TOTAL BENEFITS (NEW AND RETROFIT COMMERCIAL BUILDINGS MARKETS)

\begin{tabular}{|c|c|c|c|c|}
\hline & Participant Group & Solar-Specific Information Need & $\begin{array}{c}\text { Are the } \\
\text { Needs } \\
\text { Adequate Iy } \\
\text { Met }\end{array}$ & $\begin{array}{c}\text { Federal } \\
\text { STT } \\
\text { Assistance } \\
\text { Necessary }\end{array}$ \\
\hline (1) & Solar manufacturers and dealers & $\begin{array}{l}\text { System installation and mainte- } \\
\text { nance information }\end{array}$ & No & Yes \\
\hline (2) & Solar manufacturers and dealers & $\begin{array}{l}\text { System design and performance } \\
\text { information }\end{array}$ & No & Yes \\
\hline (3) & Solar manufacturers and dealers & $\begin{array}{l}\text { Lists of qualified installers and } \\
\text { maintainers }\end{array}$ & No & Yes \\
\hline (4) & Mechanical engineers & $\begin{array}{l}\text { System design and performance } \\
\text { information }\end{array}$ & No & Yes \\
\hline (5) & $\begin{array}{l}\text { Federal system integration } \\
\text { agencies }\end{array}$ & $\begin{array}{l}\text { System design and performance } \\
\text { information }\end{array}$ & No & Yes \\
\hline (6) & $\begin{array}{l}\text { Federal system integration } \\
\text { agencies }\end{array}$ & $\begin{array}{l}\text { System installation and mainte- } \\
\text { nance information }\end{array}$ & No & Yes \\
\hline (7) & Solar manufacturers and dealers & $\begin{array}{l}\text { Lists of qualified installers and } \\
\text { maintainers }\end{array}$ & No & Yes \\
\hline (8) & Mechanical engineers & $\begin{array}{l}\text { System installation and mainte- } \\
\text { nance information }\end{array}$ & No & Yes \\
\hline
\end{tabular}


TABLE IV-7 (Concluded)

THE MOST IMPORTANT INEORMAT-ON NEEDS OF P.ARTICIPAVT GROUPS, RANKED IN TERMS OF TOTAL BENEFITS (NEW AND RETROFIT COMMEFCIAL BUILDINGS MARKET)

\begin{tabular}{|c|c|c|c|c|}
\hline & Participant Group & Solar-Specific Information Need & $\begin{array}{l}\text { Fre the } \\
\text { Needs } \\
\text { Adequately } \\
\text { Met }\end{array}$ & $\begin{array}{l}\text { Federal } \\
\text { STT } \\
\text { Assistance } \\
\text { Necessary }\end{array}$ \\
\hline $\begin{array}{l}(9) \\
(10)\end{array}$ & $\begin{array}{l}\text { Solar manufacturers ard dealers } \\
\text { Federal system integration } \\
\text { agencies }\end{array}$ & $\begin{array}{l}\text { Lists of qualified designers } \\
\text { Lists of qualified installers ard } \\
\text { maintainers }\end{array}$ & No & $\begin{array}{l}\text { Yes } \\
\text { Yes }\end{array}$ \\
\hline (11) & $\begin{array}{l}\text { Federal system integration } \\
\text { agencies }\end{array}$ & Lists of qualified designers & No & Yes \\
\hline (12) & Mechanical contractors & $\begin{array}{l}\text { System installation and mainte- } \\
\text { nance information }\end{array}$ & No & Yes \\
\hline (13) & Mechanica: engine $ə r s$ & System cost information & Yes & \\
\hline (14) & $\begin{array}{l}\text { Federal spstem integration } \\
\text { agencies }\end{array}$ & Economic viability information & No & Yes \\
\hline (15) & $\begin{array}{l}\text { Federal sistem integration } \\
\text { agencie }\end{array}$ & Jenonstration program results & No & Yes \\
\hline
\end{tabular}

SOURCE: MITRE $\equiv$ IP Model 
TABLE IV-8

THE MCST IIPORTANT INFORMATION NEEDS OF PARTICIPANT GROUPS, RANKED IN TERMS OF TOTAL BENEFITS (AGRICULTURAL PROCESS HEAT MARKETS: RATIONAL AND TRADITIONAL FARMS)

\begin{tabular}{|c|c|c|c|c|}
\hline & Participant Group & Solar-Specific Information Need & $\begin{array}{c}\text { Are the } \\
\text { Needs } \\
\text { Adequately } \\
\text { Met }\end{array}$ & $\begin{array}{c}\text { Federal } \\
\text { STT } \\
\text { Assistance } \\
\text { Necessary }\end{array}$ \\
\hline (1) & So-ar manufacturers & $\begin{array}{l}\text { System design and performance } \\
\text { information }\end{array}$ & No & Yes \\
\hline (2) & Solar manufacturers & $\begin{array}{l}\text { System installation and mainte- } \\
\text { nance information }\end{array}$ & No & Yes \\
\hline (3) & Solar APH equipment dealers & $\begin{array}{l}\text { Lists of qualified installers and } \\
\text { maintainers }\end{array}$ & No & Yes \\
\hline (4) & Solar manufacturers & $\begin{array}{l}\text { Lists of qualified installers and } \\
\text { maintainers }\end{array}$ & No & Yes \\
\hline (5) & Solar APH equipment dea-ers & $\begin{array}{l}\text { System installation and mainte- } \\
\text { nance information }\end{array}$ & No & Yes \\
\hline (6) & Solar $\mathrm{APH}$ equipment dealers & $\begin{array}{l}\text { System design and performance } \\
\text { information }\end{array}$ & No & Yes \\
\hline (7) & Solar manufacturers & Market potential information & No & Yes \\
\hline (8) & $\begin{array}{l}\text { Federal system integration } \\
\text { agencies }\end{array}$ & $\begin{array}{l}\text { System design and performance } \\
\text { information }\end{array}$ & No & Yes \\
\hline
\end{tabular}


TLBLE IV-8 ‘Concluded)

THE MOST IMPORTANः INFORMETION NEEDS OF PARTICI?ANT GROUPS, RANKED IN TERMS CF TOTAL BENEFITS (AGRICULTJRAL PROCESS HEAT MARKETS: RATIONAL AND TRADITIONAL FARMS)

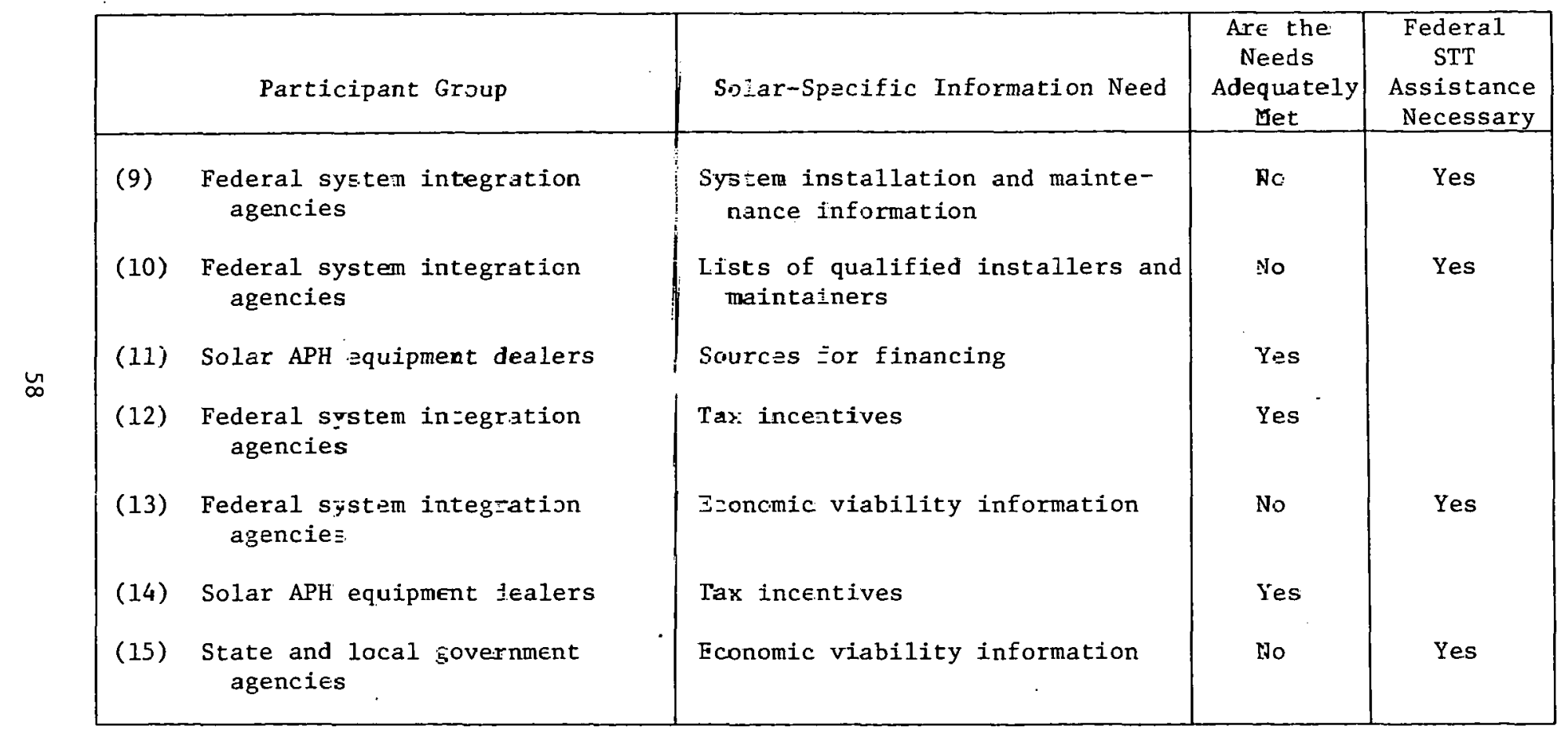

SOURCE: MITRE SIF Model 
TABLE IV-9

EQUIPMENT DECISION MAKERS IN SOLAR MARKETS

(1) New One and Two Family Homes Market (Custom Construction)

- Home Buyer

- Architect

- Mortgage Lender

- Construction Financier

(2) New One and Two Family Homes Market (Speculative and Tract Construction)

- Housing Developer

- Construction Financier

- Mortgage Lender

- Mechanical Contractor

- Mechanical Engineer

(3) New Mobile Homes Market

- Mobile Home Manufacturer

(4) One and Two Family Homes Retrofit Market (Including Mobile Homes)

- Homeowner

- Mechanical Contractor

- Financier

(5) New and Retrofit Commercial Buildings Markets

- Developer or Building Owner

- Architect

- Mechanical Engineer

- Mechaniral Contractor

- Mortgage Lender

- Construction Financier

(6) Argricultural Process Heat Markets (Rational and Traditional Farms Markets)

- Farmer

- APH Equipment Dealer

- Financier

- A\&E F1rm (In the Case of Large, Complex Projects)

- Mechanical Contractor (In the Case of Large Projects) 
Coluzzi, M., Rebibo, K. and Spewak, P., "Solar Energy Technology Transfer Model--Progam Description and Logic" (WP-12736), The MITRE Corporation, McLean, VA, 1978.

Hewett, R. et al. Solar Technology Transfer Source Book: Volume I, Buildings, Volume II, Agriculture (MTR-7674), The MITRE Corporation, McLean, VA 1978.

U1trasystems, Incorporated, A Market Study of Energy-Related Equipments for the Commercial Buildings Sector, Newport Beach, CA, 1976. 
DISTRIBUTION LIST

W- 50

R. Foreman

J. Golden

R. Greeley

R. Ouellette (25)

R. Pikul

D. Sluyter

W-50 Data File (12)

W-50 Division Staff Members

F. Eldridge

W-51

L. Gsellman

E. Sharp

W-52

G. Bennington

P. Curto

H. Dhillon

N. Gadsby (5)

R. Hewett (10)

W. Jacobsen

C. Neves

K. Rebibo

D. Salo

M. Scholl

P. Spewak

W-53

E. Ward

T. Wright
W-54

R. Chais

E. Krajeski

S. Lubore

W-55

N. Coates

R. Lay

J. Stone

W-56

P. Clifford

L. Thomas

W-57

A. Autio

S. Lewis

W-58

G. Erskine

METREK Library

Document Control (5)

Sponsor (10)

Solar Energy Technology Transfer

Consultative Committee (20)

SERI （5）

Regional Solar Energy Centers (8) 